\title{
KONSTYTUCYJNA ZASADA ODDZIELENIA PAŃSTWA OD KOŚCIOŁA W DZIAŁALNOŚCI WYDZIAŁU DO SPRAW WYZNAŃ URZĘDU WOJEWÓDZKIEGO W KROŚNIE WOBEC KOŚCIOŁA KATOLICKIEGO ${ }^{1}$
}

Działalność administracji wyznaniowej w okresie Polskiej Rzeczypospolitej Ludowej nie została w pełni opracowana w literaturze. Analogiczna sytuacja dotyczy terytorium południowo-wschodnich województw PRL, gdzie jak dotąd w znacznej części opracowano jedynie aktywność Wydziału do Spraw Wyznań przy Prezydium Wojewódzkiej Rady Narodowej w Rzeszowie do roku 1975². W roku tym przeprowadzono reorganizację struktur administracji państwowej PRL powołując 49 województw, a przy każdym z urzędów wojewódz-

* Mgr. lic., doktorant w Katedrze Prawa Wyznaniowego, Wydział Prawa, Prawa Kanonicznego i Administracji, Katolicki Uniwersytet Lubelski Jana Pawła II, Al. Racławickie 14, 20-950 Lublin, e-mail: konrad.dyda@gmail.com.

${ }^{1}$ Artykuł stanowi wynik badań zrealizowanych w ramach zadania badawczego Działalność organów administracji wyznaniowej wobec wspólnot religijnych w Polsce poludniowo-wschodniej w latach 1975-1989.

${ }^{2}$ Lidia Fiejdasz, Stosowanie prawa przez Wydziat do Spraw Wyznań w Rzeszowie wobec duchownych Kościoła katolickiego w latach 1950-1973 (Lublin: Wydawnictwo KUL, 2012); Taż, „Opór społeczeństwa Rzeszowszczyzny wobec działań Wydziału do Spraw Wyznań”, Studia z Prawa Wyznaniowego 13 (2010): 117-142; Taż, „Organizacja referatów do spraw wyznań przy prezydiach powiatowych rad narodowych w latach 1950-1957 na terenie województwa rzeszowskiego", Prace Historyczno-Archiwalne 22 (2010): 169-182; Taż „Rola Wydziału do Spraw Wyznań Prezydium Wojewódzkiej Rady Narodowej w Rzeszowie w laicyzacji służby zdrowia”, Studia z Prawa Wyznaniowego 12 (2009): 99-218. 
kich wydział do spraw wyznań ${ }^{3}$. Obszar dawnego województwa rzeszowskiego $\mathrm{w}$ przeważającej części znalazł się w jurysdykcji nowo powołanych województw krośnieńskiego, przemyskiego, tarnobrzeskiego i rzeszowskiego.

Celem niniejszego artykułu jest zaprezentowanie głównych problemów pracy Wydziału do Spraw Wyznań Urzędu Wojewódzkiego w Krośnie. Dotychczas zagadnienie to nie było podejmowane w literaturze, stąd też pełne omówienie tej problematyki znacząco przekracza ramy jednego artykułu. Dlatego ograniczono się do zaprezentowania na podstawie reprezentatywnych materiałów źródłowych ${ }^{4}-$ metod realizacji w województwie krośnieńskim konstytucyjnej zasady oddzielenia państwa od kościoła. Wybór tej perspektywy badawczej podyktowany jest faktem, iż w wielu dokumentach Wydziału do Spraw Wyznań w Krośnie pojawia się w uzasadnieniu do konkretnych przedsięwzięć, czy decyzji stwierdzenie, iż są one podejmowane w celu realizacji właśnie tej zasady.

W artykule po omówieniu zasadniczych uwarunkowań konstytucyjnych prowadzenia polityki wyznaniowej w okresie Polskiej Rzeczypospolitej Ludowej zostaną zaprezentowane podstawowe kierunki działalności administracji wyznaniowej województwa krośnieńskiego, ze szczególnym uwzględnieniem problematyki budownictwa sakralnego i kościelnego.

\section{ZASADY RELACJI POMIĘDZY PAŃSTWEM A KOŚCIOŁEM} W KONSTYTUCJI POLSKIEJ RZECZYPOSPOLITEJ LUDOWEJ

Funkcjonowanie państwa komunistycznego opierało się na podstawowej zasadzie zwierzchnictwa partii „ludu pracującego" nad aparatem państwowym ${ }^{5}$, a polityka wyznaniowa w zamyśle ideologów Polski Ludowej miała być jednym z instrumentów budowania socjalistycznego

${ }^{3}$ Ustawa z dnia 28 maja 1975 r. o dwustopniowym podziale administracyjnym Państwa oraz o zmianie ustawy o radach narodowych, Dz. U. z 1975 r. Nr 16, poz. 91.

${ }^{4}$ Materiały pochodzą z: Archiwum Akt Nowych (dalej: AAN) i Oddziału Instytutu Pamięci Narodowej w Rzeszowie (dalej: IPN-Rz).

${ }^{5}$ Henryk Leszczyna, „Kilka uwag na temat demokracji socjalistycznej”, Studia Iuridica. Problemy demokracji socjalistycznej 7 (1980): 45-46. 
państwa i społeczeństwa. W. Mysłek sklasyfikował jej cztery podstawowe zasady: uznanie religii za sprawę prywatną obywateli, wolność sumienia i wyznania, rozdział kościoła od państwa oraz nadzór suwerennego państwa nad związkami wyznaniowymi. Treścią pierwszej z nich było uznanie, że religia to prywatny problem jednostki, który nie może determinować jej poczynań w życiu publicznym. Teoretycy marksizmu wskazywali, że religia jest jednym z czynników krępujących wolność sumienia, będącą prawem do swobodnego podejmowania decyzji oraz do wolnego i nieskrępowanego wyboru odpowiadającego człowiekowi światopoglądu. Dlatego za warunek wyzwolenia człowieka uznawano likwidację jakiejkolwiek świadomości religijnej w społeczeństwie ${ }^{6}$. Stąd też wolność sumienia i wyznania polegała na prawie do wyboru światopoglądu religijnego, jednak nie dawała prawa do postępowania w życiu publicznym zgodnie z wybranymi zasadami, ograniczając się jedynie do sprawowania aktów kultu ${ }^{7}$. Niejako konsekwencją tej zasady był rozdział kościoła od państwa rozumiany jako rozdział kościoła od jakiegokolwiek życia publicznego, a co za tym idzie jego pełna laicyzacja. Rozdział kościoła od państwa nie oznaczał rozdziału państwa od kościoła, stąd wskazanie na prawo do „nadzoru” państwowego nad wspólnotami religijnymi. Warto wspomnieć, że - jak wskazywał W. Mysłek (jeden z czołowych przedstawicieli doktryny prawa wyznaniowego Polski Ludowej) - polityka wyznaniowa PRL była określana przez nadrzędne wobec prawa zasady polityczne ${ }^{8}$. Stąd też - co jest jasne w świetle współczesnego stanu badań - to pryncypia polityczne, a nie normy prawne w przeważającej mierze decydowały o postępowaniu władz komunistycznych wobec związków wyznaniowych. Pomimo tego część ze wskazanych zasad politycznych znalazła swoje odzwierciedlenie w normach konstytucyjnych, których zgodnie z nauką prawa komunistycznego głównym celem było ustanowienie zasad odpowiadających ,,interesom, dążeniom i poglądom politycznym klasy panują-

${ }^{6}$ Albin Biliński, Marksistowska a katolicka koncepcja wolności sumienia $i$ wyznania (Poznań: Politechnika Poznańska. Materiały historyczno-metodyczne, 1973), 29.

7 Józef Krukowski, Kościól i państwo. Podstawy relacji prawnych (Lublin: Redakcja Wydawnictw Katolickiego Uniwersytetu Lubelskiego, 1993), 70.

${ }^{8}$ Wiesław Mysłek, Kształtowanie stosunków społeczno-wyznaniowych $w$ Polsce Ludowej, IPN-Rz-62/139, k. 41-45. 
cej"9. Dlatego dla marksistów zasady prawa były ściśle powiązane z ich ideologią i wyrażały w sposób bezpośredni lub pośredni poglądy i wartości wyznawane przez budowniczych państwa socjalistycznego ${ }^{10}$.

Konstytucja Polskiej Rzeczypospolitej Ludowej z 22 lipca 1952 roku ${ }^{11}$ stanowiła, że PRL zapewnia swoim obywatelom wolność sumienia i wyznania, a Kościół i inne związki wyznaniowe mogą swobodnie wypełniać swoje funkcje religijne (art. 70 ust. 1). Ponadto, zgodnie z radzieckim wzorem, w Konstytucji zapisano, że kościół jest oddzielony od państwa (art. 70 ust. 2). W ówczesnej doktrynie zamiennie stosowano określenia „oddzielenie” i „rozdział” kościoła od państwa, odnosząc tą zasadę do wszystkich związków wyznaniowych działających na terytorium PRL. Należy pamiętać, że w Polsce Ludowej nie uznawano związków wyznaniowych i ich jednostek organizacyjnych za organizacje społeczne „ludu pracującego”, w których obywatelom poręczono prawo zrzeszania się (art. 72 Konstytucji). Status ten mógł zostać przyznany jedynie na podstawie wyraźnego uregulowania prawnego ${ }^{12}$. Stąd też kościołom odmawiano prawa do prowadzenia działalności politycznej, społecznej, gospodarczej lub kulturalnej uznając je za organizacje o specjalnym reżimie prawnym powołane do wykonywania jedynie funkcji religijnych ${ }^{13}$. W praktyce za spełnianie tych funkcji uznawano jedynie sprawowanie kultu w obrębie miejsc sakralnych i to w sposób uniemożliwiający jakiekolwiek oddziaływanie ich na otoczenie ${ }^{14}$, co korespondowało z komunistyczną koncepcją

${ }^{9}$ Prawo państwowe Polskiej Rzeczypospolitej Ludowej, red. Janina Zakrzewska (Łódź-Warszawa: Państwowe Wydawnictwo Naukowe, 1964), 49.

${ }^{10}$ Grzegorz Leopold Seidler, Henryk Groszyk, Jan Malarczyk, Wstęp do teorii państwa i prawa (Lublin: Uniwersytet Marii Curie-Skłodowskiej, 1982), 177.

${ }^{11}$ Konstytucja Polskiej Rzeczypospolitej Ludowej uchwalona przez Sejm Ustawodawczy w dniu 22 lipca 1952 r., Dz. U. z 1952 r. Nr 33, poz. 232 z późń. zm.

${ }^{12}$ Anna Turska, ,Zasady samorządności społecznej w świetle teorii i praktyki samorządu mieszkańców", Studia Iuridica. Problemy demokracji socjalistycznej 7 (1980): 51.

${ }^{13}$ Henryk Świątkowski, Wyznaniowe prawo państwowe. Problematyka prawna wolności sumienia w PRL, (Warszawa: Państwowe Wydawnictwo Naukowe, 1962), 139; Wiesław Lang, Jerzy Wróblewski, Sylwester Zawadzki, Teoria państwa i prawa, wyd. III zmienione (Warszawa: Państwowe Wydawnictwo Naukowe, 1986), 324.

${ }^{14} \mathrm{Za}$ znamienną w tym zakresie należy uznać przyjętą przez Urząd do Spraw Wyznań wykładnię przepisów dotyczących instalowania urządzeń nagłaśniających w kościołach. Zgodnie z art. 29 ust. 2 ustawy z dnia 26 stycznia 1984 r. Prawo prasowe (Dz. U. z 1984 r. 
wolności sumienia i wyznania jako „uwolnienia od religii” jednostki i społeczeństwa. Treścią zasady oddzielenia państwa od kościoła było uznanie pełnej suwerenności i niezależności władzy państwowej od kościelnej oraz „nadrzędności państwowej racji stanu nad kościelną racją stanu"15. Z zasady tej wynikał zakaz powierzania związkom wyznaniowym pełnienia jakichkolwiek funkcji władzy publicznej $\mathrm{i}$ ingerencji państwa $\mathrm{w}$ działalność religijną kościołów ${ }^{16}$ przy zachowaniu prawa kontroli ich pozareligijnej aktywności. W praktyce za „działalność religijną” uznawano tylko sprawowanie obrzędów liturgicznych z wyłączeniem głoszenia kazań, które często klasyfikowano jako działanie na szkodę PRL.

Ówczesny teoretyk J.F. Godlewski uważał, że rozdział kościoła i państwa jest podstawową gwarancją wolności sumienia i wyznania, pozwalającą organom państwa na ,bezstronne i jednakowe” traktowanie każdego obywatela. Autor ten za konsekwencję rozdziału uznał świeckość państwa - zakaz łącznia uroczystości państwowych i religijnych, umieszczania „emblematów” religijnych w budynkach publicznych, nauczania religii w szkołach - dzięki której państwo staje się

$\mathrm{Nr} 5$, poz. 24), kościoły i związki wyznaniowe zostały zwolnione z obowiązku uzyskania zezwolenia na zainstalowanie ich wewnątrz budynków kościołów, kaplic i przeznaczonych wyłącznie do tych celów domów modlitwy, jeżeli dźwięki wzmocnione tymi urządzeniami nie zakłócają spokoju w sąsiednich budynkach. Urząd do Spraw Wyznań stwierdził, że „wykładnia tego przepisu jest utrudniona przez fakt, iż nie określa on przesłanek ocennych - co może być uznane za zakłócenie spokoju, a co nie. (...) Przez «obręb kościoła» należy rozumieć również przestrzeń wokół niego, najczęściej ogrodzoną i wykorzystywaną dla celów tradycyjnych procesji organizowanych w czasie nabożeństw, czy też innych tradycyjnych obrzędów. Może to być również cmentarz przykościelny. Jeżeli jest to natomiast kościół znajduje się w zwartej zabudowie ulicy lub ruchliwy węzeł komunikacyjny - to wówczas przez obręb kościoła należy rozumieć tylko jego wnętrze i taką przestrzeń przed kościołem, której zajęcie nie zakłóca głównego jej przeznaczenia. Jeśli więc zainstalowane w kościele urządzenia nagłośniające przenoszą dźwięk poza tak określony obszar - można uznać, że jest to naruszenie warunku, od którego uzależnione jest zwolnienie z obowiązku wcześniejszego uzyskania zezwolenia na zainstalowanie urządzeń nagłaśniających”, Urządzenia nagłaśniające, AAN, zespół 1587, sygn. 145/21, k. 1-2.

${ }^{15}$ Jerzy Feliks Godlewski, Realizacja zasady wolności sumienia w PRL a jej funkcjonowanie $w$ krajach kapitalistycznych, mps w: Bibliotece Uniwersyteckiej Katolickiego Uniwersytetu Lubelskiego Jana Pawła II, s. 18.

${ }^{16}$ Janusz Grudzień, Zasady polityki wyznaniowej PRL. Wydanie trzecie poprawione i uzupetnione (Warszawa: Książka i Wiedza, 1971), 36. 
„świeckie, suwerenne, niezależne od religii i kościoła” ${ }^{17}$. Dla W. Mysłka zasada ta oznaczała ,pełną sekularyzację pozawyznaniowych aspektów życia społecznego", a co za tym idzie uniemożliwienie związkom wyznaniowym prowadzenia szkół, szpitali i innych placówek opiekuńczych, wydawania własnej prasy, czy posiadania udziałów w „kapitale finansowym i przemysłowym"18. Jeszcze u schyłku PRL J. Osuchowski wskazywał, że „przyszła konstytucja powinna utrzymać dotychczasowe rozwiązania w postaci zasady rozdziału Kościoła od państwa, dla której nie może być żadnej alternatywy"19.

Przekonanie o tożsamości normatywnej pojęć „rozdział” i „oddzielenie" występuje także we współczesnej doktrynie prawa wyznaniowego. Za rozumieniem tej zasady jako rozdziału Kościoła od PRL opowiada się m.in. M. Pietrzak ${ }^{20}$, B. Górowska ${ }^{21}$, J. Dziobek-Romański²2, a M. Olszówka wyjaśnia, że ,użycie słowa «oddzielony» miało oznaczać (...) wprowadzenie systemu rozdziału kościoła od państwa, nie przesądzając - przynajmniej brzmieniem rozważanego artykułu - charakteru separacji (skoordynowana czy wroga?)"23. Tezę o chęci przyjęcia modelu rozdziału kościoła od państwa przez ustrojodawcę komunistycznego potwierdza wykładnia historyczna Konstytucji z 1952 roku. W grudniu 1948 roku Kongres PZPR uchwalił deklarację ideową, w której stwierdzono, że ,partia stoi na gruncie rozdziału Kościoła od państwa, na gruncie świeckości szkolnictwa i wszel-

${ }^{17}$ Jerzy Feliks Godlewski, Założenia polityki wyznaniowej w PRL (Warszawa: Wyższa Szkoła Nauk Społecznych przy KC PZPR, 1984), 14-15.

${ }^{18}$ Wiesław Mysłek, Polityka wyznaniowa Polski Ludowej. Przesłanki i realizacja (Warszawa: Państwowe Wydawnictwo „Iskry”, 1970), 145-147.

${ }^{19}$ Janusz Osuchowski, „Wolność sumienia i wyznania w przyszłej konstytucji PRL”, Państwo i Prawo 5 (1989): 39.

${ }^{20}$ Michał Pietrzak, Demokratyczne, świeckie państwo prawne (Warszawa: Wydawnictwo LIBER, 1999), 166.

${ }^{21}$ Beata Górowska, „Rozdział kościoła i państwa w PRL”, w: Francuska ustawa z 9 grudnia 1905 roku o rozdziale kościołów i państwa z perspektywy stu lat, red. Michał Pietrzak (Warszawa: Wydawnictwo LIBER, 2007), 182.

${ }^{22}$ Jacek Dziobek-Romański, „Ewolucja normatywna regulacji stosunków państwo-Kościół w Polsce Ludowej (1944-1989)", w: Bilateralizm w stosunkach państwowo-kościelnych, red. Marek Bielecki (Lublin: Wydawnictwo KUL, 2011), 63.

${ }^{23}$ Marcin Olszówka, Konstytucja PRL a system źródel prawa wyznaniowego do roku 1989 (Warszawa: Oficyna Wydawnicza Uczelni Łazarskiego, 2016), 60. 
kich instytucji publicznych"24. Z analizy dyskusji toczonej na forum Sejmu nad Konstytucją w 1952 roku wynika, że zdawano sobie sprawę z niejednoznaczności pojęcia rozdziału kościoła od państwa, który w praktyce może przybrać różnorodne formy. Jednak wątpliwości te rozwiał przewodniczący Komisji Konstytucyjnej B. Bierut mówiąc, że „nie wyraża ona nic nowego, wyraża krótko i węzłowo faktycznie istniejący stan rzeczy"25. Biorąc pod uwagę ówcześnie prowadzone działania wobec Kościoła Katolickiego należy stwierdzić, że intencją twórców Konstytucji PRL było usankcjonowanie represyjnej polityki wobec niego. Ogólnikowość pojęć zastosowanych w ustawie zasadniczej z 1952 roku umożliwiała swobodną interpretację zasad konstytucyjnych, a co za tym idzie wyprowadzanie z nich dowolnych rozwiązań kwestii szczegółowych ${ }^{26}$. H. Misztal zauważa, że model ten w polskiej praktyce okazał się ,,zwierzchnictwem państwa nad Kościołem”27. Stąd też nie ma wątpliwości, że Konstytucja PRL przyjęła sowiecki model rozdziału kościoła i państwa ${ }^{28}$, zarówno w formie terminologicznej, jak i praktycznego działania aparatu państwa.

Zasady relacji pomiędzy państwem i związkami wyznaniowymi choć muszą mieć podstawy jurydyczne ${ }^{29}$, to o faktycznej ich treści świadczy praktyczna aplikacja w sferze wzajemnych stosunków. Szczegółowe

${ }^{24}$ Krzysztof Krasowski, „Koncepcje regulacji stosunków między państwem a Kościołem katolickim w Polsce w latach 1945-1952 i ich realizacja”, w: Vetera novis augere. Studia i prace dedykowane profesorowi Wacławowi Uruszczakowi, t. 1, red. Stanisław Grodziski, Dorota Malec, Anna Karabowicz, Marek Stus (Kraków: Wydawnictwo Uniwersytetu Jagiellońskiego, 2010), 470.

${ }^{25}$ Jerzy Godlewski, Henryk Jabłoński, Prawo a religia (Warszawa: Wiedza Powszechna, 1988), 34-35.

${ }^{26}$ Michał Pietrzak, „Państwo i Kościół w obecnej i przyszłej konstytucji polskiej”, Rocznik Teologiczny 1 (1993): 281-285.

${ }^{27}$ Henryk Misztal, Polskie prawo wyznaniowe. Zagadnienie wstępne. Rys historyczny (Lublin: Wydawnictwo KUL, 1997), 223; por. Marian Stanisław Mazgaj, Church and State in Communist Poland. A History, 1944-1989, (McFarland \& Company, Inc., Publishers, 2010), 44.

${ }^{28}$ Jarosław Szymanek, „Kształtowanie normatywnego systemu stosunku państwa do organizacji religijnych w Związku Radzieckim”, Studia z Prawa Wyznaniowego 7 (2004): 96.

${ }^{29}$ Tenże, „Formy prawnej instytucjonalizacji rozdziału państwa i kościoła”, Studia z Prawa Wyznaniowego 11 (2008): 59. 
rozwiązania prawne i ich aplikacja w działalności aparatu państwowego są podstawowym wyznacznikiem rozumienia konstytucyjnych zasad prowadzenia polityki wyznaniowej. Oczywiście, z punktu widzenia współczesnego konstytucjonalizmu i pojmowania państwa prawa oczywistym jest, że normy niższego rzędu muszą być zgodne z ustawą zasadniczą, jednak praktyczna aplikacja tej zasady nawet w rozwiniętych demokracjach nie raz nastręcza pewne trudności. Tym bardziej w ,demokracji ludowej”, gdzie prawo było jedynie instrumentem realizacji celów ideologicznych i politycznych. Dlatego tylko poprzez badanie działalności aparatu państwowego można prawidłowo zrozumieć znaczenie jakie przyznawano proklamowanym zasadom.

W celu realizacji założeń polityki wyznaniowej Polski Ludowej powołano wyspecjalizowane jednostki - działające w ramach aparatu Ministerstwa Spraw Wewnętrznych: Departament V, Departament III, a następnie Departament IV - i powołany dnia 19 kwietnia 1950 roku Urząd do Spraw Wyznań ${ }^{30}$. Jednostki te tworzyły swoje terenowe struktury przy odpowiednich organach władzy lokalnej. W przypadku Urzędu do roku 1975 funkcjonowały Wydziały do Spraw Wyznań przy Prezydiach Wojewódzkich Rad Narodowych, a następnie - po reformie administracyjnej - analogiczne Wydziały Urzędów Wojewódzkich. Od 29 maja 1974 roku na czele Urzędu stał kierownik w randze ministra i wchodził w skład Rady Ministrów ${ }^{31}$. Kompetencje Urzędu do Spraw Wyznań zostały już w literaturze opisane, stąd też w niniejszym opracowaniu nie ma potrzeby ich ponownego omawiania. Dla prezentowanych rozważań wystarczającym jest przypomnienie, że charakterystycznym przejawem działalności Urzędu do Spraw Wyznań oraz jego jednostek terenowych było ogólnikowe - bez powoływania się na konkretne przepisy - motywowanie swoich działań aktami prawnymi. Poza tym postępowanie toczone przed organami Urzędu z reguły było niejaw-

${ }^{30}$ Ustawa o zmianie organizacji naczelnych władz państwowych w zakresie gospodarki komunalnej i administracji publicznej (Dz. U. z 1950 r. Nr 19, poz. 156); Adam Dziurok, Marek Gałęzowski, Łukasz Kamiński, Filip Musiał, Od niepodległości do niepodległości. Historia Polski 1918-1989 (Warszawa: Instytut Pamięci Narodowej - Komisja Ścigania Zbrodni przeciwko Narodowi Polskiemu, 2010), 325.

${ }^{31}$ Uchwała Sejmu Polskiej Rzeczypospolitej Ludowej z dnia 29 maja 1974 roku w sprawie powołania Ministra w składzie Rady Ministrów, MP z 1974 r. Nr 20, poz. 119. 
ne, podobnie jak materiały i ekspertyzy zgromadzone w jego toku. Praktycznie Urząd zarezerwował sobie wszystkie sprawy, w których stroną był jakikolwiek związek wyznaniowy ${ }^{32}$. Urząd do Spraw Wyznań za praktyczne przejawy wolności wyznania w PRL uznawał m.in. swobodę sprawowania kultu w obrębie kościołów i kaplic oraz nauczania religii w punktach katechetycznych, łatwość uzyskania zezwoleń administracyjnych na procesje i pielgrzymki, ograniczenie ingerencji państwa w sprawy organizacyjne i kadrowe Kościoła do „obsadzania parafii i diecezji”, czy państwową rejestrację stanu cywilnego ${ }^{33}$.

Zgodnie z poglądami wyrażanymi w doktrynie prawa komunistycznego, obywatele PRL nie mogli korzystać z ,,przyznanych im praw i wolności w celu godzenia w podstawowe zasady ustroju socjalistycznego"34. Natomiast Kościół Katolicki, z punktu widzenia ideologii komunistycznej, programowo godził w podstawowe zasady ustroju PRL. Nie dość, że stanowił organizację zrzeszającą zdecydowaną większość obywateli, to jeszcze głosił doktrynę religijną z natury sprzeczną z ideologią komunizmu. A jak wskazywał W. Jaruzelski ,kwestia sojuszy klasy robotniczej obejmuje również problematykę polityki wobec wierzących, religii i Kościoła ze strony partii uznającej naukowy światopogląd i walczącej o jego upowszechnienie i dominację" ${ }^{35}$. Stąd też za podstawę „,normali-

${ }^{32}$ Fiejdasz, Stosowanie prawa przez Wydzial do Spraw Wyznań w Rzeszowie, 21-31; Henryk Misztal, Artur Mezglewski, „Zakres kompetencji, styl działania i cele Urzędu do Spraw Wyznań,, w: Prawo i polityka wyznaniowa w Polsce Ludowej: materiały II Ogólnopolskiego Sympozjum Prawa Wyznaniowego (Kazimierz Dolny, 26-28 października 2004), red. Artur Mezglewski, Piotr Stanisz, Marta Ordon (Lublin: Wydawnictwo KUL, 2005), 36-37; Michał Krawczyk, „Organy państwowo-partyjne odpowiedzialne za wytyczanie i realizowanie polityki wyznaniowej PRL", Zeszyty Naukowe Uniwersytetu Przyrodniczo-Humanistycznego w Siedlcach 89 (2011): 215; Krukowski, Kościót i państwo. Podstawy relacji prawnych, 201-203; Józef Majka, „Kościół w Polsce po drugiej wojnie światowej”, Chrześcijanin w Świecie 1 (1994): 6-22.

${ }^{33}$ Zasady i zadania polityki wyznaniowej (swobody konstytucyjne, polityka porozumienia), AAN zespół 1587, sygn. 142/4, k. 8-9.

${ }^{34}$ Bogusław Banaszak, „Konstytucyjne założenia podstawowych praw, wolności i obowiązków obywatelskich i ich realizacja w praktyce", w: Konstytucja PRL po 30 latach jej obowiazywania, red. Kazimierz Działocha (Wrocław: Wydawnictwo Uniwersytetu Wrocławskiego, 1983): 125.

${ }^{35}$ Wystapienie Wojciecha Jaruzelskiego na II Ogólnopolskiej Partyjnej Konferencji Ideologiczno-Teoretycznej, 27.11.1985 r., AAN, zespół 1587, sygn. 148/34, k. 86. 
zacji” stosunków pomiędzy PRL a Kościołem Katolickim - w sytuacji niemożności włączenia tego związku wyznaniowego w ,proces przemian socjalistycznych" - uznano uniemożliwienie mu stania się alternatywą dla państwa socjalistycznego ${ }^{36}$. W tym celu podejmowano szereg działań mających na celu „dezintegrację” Kościoła ${ }^{37}$. Spośród niezliczonej liczby tego typu czynności wystarczy przywołać tylko tę jedną. Wydział w Jeleniej Górze podsumowując pierwszy okres swojej działalności raportował Urzędowi do Spraw Wyznań, że wykorzystując konflikt do jakiego doszło pomiędzy proboszczem i wikariuszem w miejscowości Lubawka, doprowadził do tego, że utworzono parafię polskokatolicką, do której należało 200 osób $^{38}$.

Jedną z charakterystycznych cech stosowania prawa przez administrację wyznaniową było różnicowanie aplikacji jednolitych przepisów obowiązującego prawa na podstawie pozaprawnych i arbitralnie przyjętych przesłanek. Przykładowo, Wydział w Białej Podlaskiej rozstrzyganie spraw administracyjnych zgodnie z pryncypiami polityki wyznaniowej uczynił jedną z zasad swojego działania39; Wydział w Bielsku-Białej za podstawowe czynniki determinujące swoje postępowanie uznał normy prawne, zasady współżycia społecznego oraz wytyczne kierownictwa politycznego i resortowego ${ }^{40}$. Sąsiedni do krośnieńskiego - Wydział do Spraw Wyznań w Przemyślu - wprost stwierdzał, że prowadzi politykę wyznaniową „pod kierownictwem” I Sekretarza KW PZPR ${ }^{41}$. W dokumentach Urzędu do Spraw Wyznań

${ }^{36}$ Zasady i zadania polityki wyznaniowej (swobody konstytucyjne, polityka porozumienia), AAN zespół 1587, sygn. 142/4, k. 16.

${ }^{37}$ Marek Lasota, „Zadanie: dezintegracja Kościoła w Polsce”, w: Znak, któremu sprzeciwiać się będa. Komunistyczne państwo wobec Kościoła w Polsce, red. Jarosław Szarek (Kraków: Instytut Pamięci Narodowej - Komisja Ścigania Zbrodni przeciwko Narodowi Polskiemu oddział w Krakowie, 2004), 69-78.

${ }^{38}$ Charakterystyka i ocena wyników polityki wyznaniowej $w$ okresie od 1.IX.1975-1. IX.1977, AAN, zespół 1587, sygn. 127/67, k. 76.

${ }^{39}$ Informacja o pracy Wydziału do Spraw Wyznań UWw Białej Podlaskiej i próba oceny polityki wyznaniowej w okresie IX 1975-IX 1977, AAN, zespół 1587, sygn. 127/67, k. 8.

${ }^{40}$ Charakterystyka i ocena wyników polityki wyznaniowej w okresie od 1.09.1975 do 1.09.1977 na terenie województwa bielskiego, AAN, zespół 1587, sygn. 127/67, k. 18.

${ }^{41}$ Charakterystyka i ocena wyników polityki wyznaniowej na terenie woj. przemyskiego obejmująca okres od 1.09.1975-1.09.197 r., AAN, zespół 1587, sygn. 127/67, k. 225. 
można odnaleźć materiały świadczące o tym, że ocena stosunku poszczególnych duchownych, a nawet całych diecezji, czy zgromadzeń zakonnych do Polski Ludowej miała decydujący wpływ na podejmowanie decyzji administracyjnych. Jako przykład warto wskazać pismo Aleksandra Merkera do dyrektora wrocławskiego Wydziału w sprawie umożliwienia kontynuacji budowy obiektu mieszkalno-gospodarczego w Krzydlinie Małej przez Zgromadzenie Misjonarzy Klaretynów. Ówczesny Dyrektor Urzędu prosił o ponowne rozpatrzenie tej sprawy „biorąc pod uwagę lojalną postawę władz tego zgromadzenia wobec państwa"42. Należy pamiętać, że ocena postaw duchownych czy jednostek kościelnych była dokonywana przez władze PRL w sposób niezwykle arbitralny, często pozbawiony uzasadnienia. Analizując dokumenty archiwalne łatwo można zauważyć nieostrość klasyfikacji przyjmowanych dla oceny ,postawy politycznej” duchownych. W celu jej rozpoznania organy administracji i bezpieczeństwa prowadziły charakterystyki osób duchownych i ich akta osobowe, które przesyłano do odpowiednich jednostek wraz ze zmianą miejsca zamieszkania duchownego. W samym roku 1986 krośnieński Wydział do Spraw Wyznań korespondował ze swoimi odpowiednikami w sprawie przesyłania akt osobowych i charakterystyk 66-ciu duchownych, którzy opuszczali lub przybywali na terytorium województwa ${ }^{43}$.

\section{ORGANIZACJA WYDZIAŁU DO SPRAW WYZNAŃ \\ URZĘDU WOJEWÓDZKIEGO W KROŚNIE \\ I GŁÓWNE KIERUNKI JEGO DZIAŁALNOŚCI}

Pierwszym wojewodą krośnieńskim został Wojciech Grochala, który pełnił tę funkcję do końca 1977 roku. Został zastąpiony przez Stanisława Szczepańskiego. Kolejna zmiana na tym stanowisku nastą-

${ }^{42}$ Pismo Aleksandra Merkera do Towarzysza Mieczystawa Prajsnera Dyrektora Wydziatu do Spraw Wyznań Urzędu Wojewódzkiego we Wrocławiu z dnia 25 sierpnia 1986 roku, AAN, zespół 1587, sygn. 142/47, k. 1.

${ }^{43}$ Akta osobowe osób duchownych i zakonnych, IPN-Rz-62/15, k. 1-3; Wykaz osób duchownych - zakonników zamieszkatych na terenie Miasta i Gminy Dukla wg stanu na dzień 31.12.1979 r., IPN-Rz-61/95, k. 11-12. 
piła 27 maja 1980 roku, kiedy urząd wojewody objął Tadeusz Kruk sprawujący go aż do 1989 roku. Organizacja krośnieńskiej administracji wojewódzkiej napotykała na znaczne trudności, zwłaszcza w zakresie odpowiedniej bazy lokalowej dla 20-stu wydziałów Urzędu Wojewódzkiego. Ich siedziby na terenie miasta zlokalizowano w 13-stu różnych budynkach ${ }^{44}$. Wydział do Spraw Wyznań usytuowano w trzech pomieszczeniach hotelu robotniczego Krośnieńskiego Przedsiębiorstwa Budowalnego - co ze względu na znaczną odległość od głównej siedziby Urzędu Wojewódzkiego, brak księgozbioru opracowań kwestii wyznaniowych i wewnętrznego połączenia telefonicznego - powodowało poważne utrudnienia w prowadzeniu administracji wyznaniowej. Pierwszym dyrektorem krośnieńskiego WdSW został mgr Z. Liczmański, a kolejnym W. Serwatka. Poza nim w Wydziale pracowały trzy osoby: Inspektor wojewódzki tow. Stanisław Pięta (pół etatu), Inspektor tow. Michalina Dębiec - odpowiedzialna za zakony żeńskie oraz Starszy Inspektor tow. Adam Danecki. Spośród pracowników wszyscy byli członkami PZPR, a wyższe wykształcenie posiadał jedynie Dyrektor. W tamtym czasie A. Danecki deklarował chęć kontynuowania przerwanych studiów prawniczych ${ }^{45}$. W 1982 roku wskazywano na problemy kadrowe związane z małą liczbą pracowników oraz urlopem macierzyńskim jednej z pracownic ${ }^{46}$. Stąd też w kolejnym roku zwiększono obsadę personalną Wydziału. Od 1 stycznia 1983 roku liczył on czterech pracowników: Dyrektor J. Chlebuś - pracujący w nim od 2 lat będący także lektorem KW PZPR, Starszy Inspektor L. Chomentowski - pracował od 1.5 roku, Starszy Referent M. Kluz, która rozpoczęła pracę we wrześniu 1982 roku. W tym czasie zmieniła się także struktura wykształcenia pracowników Wydziału. Spośród wszystkich pracowników jedynie A. Danecki posiadał wykształcenie półwyższe nauczycielskie, pozostali urzędnicy byli absolwentami prawa lub administracji.

${ }^{44}$ Dariusz Iwaneczko, Zmierzch dekady Gierka. Polska południowo-wschodnia 1875-1980 (Rzeszów: Instytut Pamięci Narodowej Komisja Ścigania Zbrodni przeciwko Narodowi Polskiemu oddział w Rzeszowie, 2016), 35-37.

${ }^{45}$ Sprawozdanie dot. sytuacji wyznaniowej i działalności Wydziału do Spraw Wyznań w 1979 roku, AAN, zespół 1587, sygn. 127/73, k. 236.

${ }^{46}$ Sprawozdanie o sytuacji wyznaniowej $i$ działalności Wydziału do Spraw Wyznań Urzędu Wojewódzkiego w Krośnie w 1982 r., IPN-Rz-62/3, k.14-18. 
Z zachowanych dokumentów wynika, że kadra odznaczała się „dużymi umiejętnościami w zakresie administracji wyznaniowej” i „należycie wykonywała swoje obowiązki". Wszystkie ważniejsze decyzje konsultowano z Wydziałem Administracyjnym KW PZPR oraz wydziałem IV Wojewódzkiego Urzędu Spraw Wewnętrznych ${ }^{47}$, ponadto Wydział w realizacji polityki wyznaniowej współpracował z Sądem Wojewódzkim, Państwowym Biurem Notarialnym, Wojewódzkim Biurem Geodezji i Terenów Rolnych oraz Wojewódzkim Biurem Planowania Przestrzennego i Nadzoru Budowlanego ${ }^{48}$. Z raportów składanych Urzędowi do Spraw Wyznań wynika, że w krośnieńskim Wydziale w każdy poniedziałek odbywały się narady Kierownika Wydziału Administracyjnego, Naczelnika Wydziału IV WUSW oraz Dyrektora WdSW podczas których przekazywano informację o bieżącej pracy struktur bezpieczeństwa wobec Kościoła ${ }^{49}$.

Spośród pracowników Wydziału najszersze kompetencje (ale ograniczone do terenu niektórych gmin) posiadał inspektor wojewódzki, do którego należał m.in. nadzór nad prawidłowym wykonaniem Dekretu o ochronie wolności sumienia i wyznania oraz przestrzeganiem prawa przez kościoły i związki wyznaniowe; udzielanie pomocy w rozwijaniu „społecznie użytecznych inicjatyw duchowieństwa” i instruktaż terenowych jednostek administracyjnych w problematyce polityki wyznaniowej; zagadnienia orzeczeń kolegiów ds. wykroczeń w stosunku do osób duchownych; koordynowanie działań w zakresie budownictwa sakralnego i kościelnego: podejmowanie natychmiastowej kontroli w przypadku ujawnienia nielegalnej budowy obiektu sakralnego, opracowywanie materiałów dot. zgłaszanych przez kurie planów budownictwa ${ }^{50}$.

$\mathrm{Na}$ terenie województwa funkcjonowały dwie diecezje Kościoła Katolickiego: tarnowska - z jednym dekanatem i siedmioma parafiami

${ }^{47}$ Wykaz pracowników Wydziału do Spraw Wyznań Urzędu Wojewódzkiego w Krośnie wg stanu na dzień 1.I.1983 r., IPN-Rz-62/3, k.5.

${ }^{48}$ Sprawozdanie o sytuacji wyznaniowej $i$ działalności Wydziału do Spraw Wyznań Urzędu Wojewódzkiego w Krośnie w 1982 r., IPN-Rz-62/138, k. 17.

${ }^{49}$ Sprawozdanie dot. sytuacji wyznaniowej i działalności Wydziału do Spraw Wyznań w 1979 roku, AAN, zespół 1587, sygn. 127/73, k. 235-236.

${ }^{50}$ Zakres czynności Inspektora Wojewódzkiego Wydziału do Spraw Wyznań ob. Stanisława Pięty, IPN-Rz-62/46, k. 7-9. 
oraz przemyska - prowadząca 14 dekanatów, 99 parafii, 41 wikariatów eksponowanych i 22 placówki duszpasterskie utworzone bez zgody władz państwowych. W 1976 roku pracowało w nich łącznie 344 księży diecezjalnych i 86 zakonnych. Ponadto w Krośnieńskiem funkcjonowało 10 domów zakonów męskich i 45 żeńskich. Stan posiadania Kościoła Katolickiego Wydział określał na 173 kościoły, 112 kaplice i 1600 ha gruntów ornych i leśnych ${ }^{51}$. W 1977 roku 18-stu księży zakwalifikowano jako pozytywnie ustosunkowanych do PRL ${ }^{52}$ i tyle samo do grupy „księży wrogich, gorliwie realizujących wytyczne hierarchii kościelnej"53, natomiast pozostałych uznano za obojętnych wobec władz komunistycznych. Za najczęściej popełniane wykroczenia przeciwko prawu państwowemu krośnieński Wydział uznawał nieprzestrzeganie przepisów dot. budownictwa sakralnego i kościelnego ${ }^{54}$. Należy pamiętać, że w ramach struktur Kościoła Katolickiego na terenie województwa krośnieńskiego funkcjonował nieuznawany przez władze komunistyczne Kościół Greckokatolicki. Poza tym w woj. krośnieńskim prowadziły działalność także inne związki wyznaniowe: Polski Autokefaliczny Kościół Prawosławny, Kościół Polskokatolicki, Kościół Adwentystów Dnia Siódmego, Zjednoczony Kościół Ewangeliczny, Świecki Ruch Misyjny „Epifania”, Zrzeszenie Wolnych Badaczy Pisma Świętego, Polski Kościół Chrześcijan Baptystów ${ }^{55}$. W dokumentach Urzędu do Spraw Wyznań można znaleźć przekonanie, że stosunki PRL ze związkami wyznaniowymi innymi niż Kościół Katolicki ,kształtują się zgodnie z zasadami konstytucyjnymi" ${ }^{56}$. W początkowym okresie swojej działalności krośnieński wydział raportował Urzędowi w Warszawie, że ze względu na małą

${ }^{51}$ Informacja o stanie posiadania i działalności kościoła rzymskokatolickiego na terenie województwa krośnieńskiego, IPN-Rz-62/139, k. 1.

${ }^{52}$ Wykaz księży pozytywnie ustosunkowanych do PRL, IPN-Rz-62/139, k. 7.

${ }^{53}$ Wykaz księży gorliwie realizujących wytyczne hierarchii kościelnej $i$ negatywnie ustosunkowanych do ustroju PRL na terenie województwa krośnieńskiego wg stanu na dzień 15.IX.1975 r., IPN-Rz-62/139, k. 8.

${ }^{54}$ Wykaz księży naruszajacych porządek prawny PRL na terenie województwa krośnieńskiego wg stanu na dzień 15.IX.1975 r., IPN-Rz-62/139, k. 9-11.

${ }_{55}^{5}$ Wykaz kościołów $i$ innych związów wyznaniowych nierzymskokatolickich $w$ woj. Krosno, IPN-Rz-62/88, k. 1.

${ }^{56}$ Zasady, problemy $i$ zadania polityki wyznaniowej w Polsce, AAN zespół 1587, sygn. 142/4, k. 18. 
liczebność wyznań nierzymskokatolickich „nie mogą one stanowić skutecznej przeciwwagi" dla Kościoła Rzymskokatolickiego, dlatego w celu dezintegracji Kościoła postanowiono rozwijać struktury takich organizacji, jak „Pax” i „Caritas”57. Poza tym na terenie województwa istniały Klub Inteligencji Katolickiej, Chrześcijańskie Stowarzyszenie Społeczne i Polski Związek Katolicko-Społeczny ${ }^{58}$.

Wydział do Spraw Wyznań koordynował realizację polityki wyznaniowej w całym województwie, zgodnie z zarządzeniem nr 46/80 wojewody krośnieńskiego wszystkie decyzje dotyczące polityki wyznaniowej miały być uzgadniane z tym Wydziałem. Jednak najważniejsze decyzje odnośnie prowadzenia polityki wyznaniowej województwa krośnieńskiego zapadały podczas narad „Trójki Wojewódzkiej”. Brali w nich udział wojewoda krośnieński, I Sekretarz Komitetu Wojewódzkiego PZPR, szef Wojewódzkiego Urzędu Spraw Wewnętrznych, dyrektor Wydziału do Spraw Wyznań oraz inne zaproszone osoby. To na tym forum omawiano podejmowane „działania dyscyplinujące wobec poczynań kleru", ważniejsze zagadnienia dotyczące budownictwa sakralnego, problemy organizowania punktów katechetycznych, czy procesji poza kościołem. W tym gronie zapadały decyzje co do skierowania określonych spraw na drogę postępowania sądowego, karno-administracyjnego, przeprowadzania rozmów ostrzegawczych, czy nagłaśniania „politycznych" wystąpień duchownych w prasie ${ }^{59}$. Przykładem podejmowania decyzji o zastosowaniu sankcji prawnych wobec duchownych w oparciu o decyzje polityczne, jest zwrócenie się w czerwcu 1980 roku z prośbą do A. Merkera o wyrażenie zgody na pociągnięcie do odpowiedzialności karnej duchownych nierespektujących przepisów dot. organizacji procesji Bożego Ciała. Wiceminister w rozmowie telefonicznej miał „wyrazić

${ }^{57}$ Pismo Urzędu Wojewódzkiego w Krośnie do Urzędu do Spraw Wyznań w Warszawie z 28 września 1977 r., AAN, zespół 1587, sygn. 127/67, k. 122.

${ }^{58}$ Informacja dot. świeckiego wychowania i obrzędowości z 20 lipca 1987 roku, IPN-Rz$62 / 7$, k. 30 .

${ }^{59}$ Działania dyscyplinujace podejmowane przez Wydziat do Spraw Wyznań w porozumieniu z kompetentnymi jednostkami w stosunku do kleru katolickiego, IPN-Rz-62/19, k. 10-12; Posiedzenie „Małej Trójki” z 16 lipca 1985 roku, IPN-Rz-62/19, k. 13; Notatka stużbowa z posiedzenia Trójki Wojewódzkiej odbytego dnia 7 czerwca 1985 roku, IPN-Rz62/19, k. 16-17; Sprawy do omówienia na posiedzeniu „,Trójki” 11 grudnia 1985 roku, IPN-Rz-62/19, k. 21 
aprobatę na ewentualne wnioski do Kolegium celem przykładnego ukarania winnych"60. Ostatecznie wnioski skierowano przeciwko pięciu kapłanom ,znanym z samowoli i naruszania porządku prawnego"61.

Główne zainteresowanie administracji wyznaniowej województwa krośnieńskiego koncentrowało się wokół działalności Kościoła Katolickiego, a zwłaszcza diecezji przemyskiej. Na samym początku funkcjonowania WdSW w Krośnie ocenił pracę duchownych tejże diecezji jako „dynamicznie prowadzoną ofensywę na trzech płaszczyznach: polityczno-ideologicznej, organizacyjnej i propagandowej”. Miała się ona przejawiać poruszaniem podczas kazań tematu sytuacji Kościoła w PRL, jego znaczenia dla obrony narodu oraz łamania postanowień wyznaniowych Konstytucji; angażowaniem wiernych w prowadzenie budownictwa sakralnego i kościelnego oraz tworzeniem nowych inicjatyw duszpasterskich, np. oaz ${ }^{62}$. Zdaniem krośnieńskiego WdSW duchowni „,wykorzystywali fanatyzm religijnych wiernych kościoła rzymskokatolickiego do walki i innymi wyznaniami uznanymi przez państwo", takimi jak „kościół prawosławny, ewangeliczny, narodowy i inne"63.

Krośnieński WdSW za główną przeszkodzę w realizacji założeń polityki wyznaniowej uważał „duży ludowy fanatyzm środowisk wiejskich” oraz ,zmiany postawy ideologicznej zaangażowanej młodzieży"64. Już po pierwszym okresie swojej działalności instancje partyjne województwa krośnieńskiego zauważały potrzebę rozszerzenia i doskonalenia ,pracy ideologicznej z nauczycielami, zwłaszcza przedmiotów ideologicznych". W tym celu aktyw PZPR zalecał upowszechnienie we wszystkich szkołach województwa wzorców wychowania socjalistycz-

${ }^{60}$ Informacja o przebiegu święta Bożego Ciała w dniu 5.06.1980 r. w woj. krośnieńskim, IPN-Rz-62/115, k. 16.

${ }^{61}$ Byli to: ks. Stanisław Matuła, ks. Józef Winnicki, ks. Kazimierz Trygar, ks. Kazimierz Kaczor, ks. Kazimierz Tomasik, Informacja o przebiegu święta Bożego Ciała $w$ dniu 5.06.1980 r. w woj. krośnieńskim, IPN-Rz-62/115, k. 18.

${ }^{62}$ Informacja o stanie posiadania i działalności kościoła rzymskokatolickiego na terenie województwa krośnieńskiego, IPN-Rz-62/139, k. 2, Punkty konfliktowe /zagrożenia/ na tle samowolnego budownictwa sakralnego na terenie woj. krośnieńskiego, IPN-Rz-62/87, k.3-4.

${ }^{63}$ Informacja o stanie posiadania i działalności kościoła rzymskokatolickiego na terenie województwa krośnieńskiego, IPN-Rz-62/139, k. 2.

${ }^{64}$ Sprawozdanie dot. sytuacji wyznaniowej $i$ działalności Wydziału do Spraw Wyznań w 1979 roku, AAN, zespół 1587, sygn. 127/73, k. 232. 
nego. Ponadto wskazywano na konieczność udoskonalenia działalności organizacji młodzieżowych przede wszystkim w celu jak najlepszego realizowania programu ideowo-wychowawczego ${ }^{65}$. W 1988 roku dyrektor Wydziału J. Chlebuś stwierdził, że „,pozorne zagrożenie laicyzacją” powoduje intensywną działalność duchowieństwa katolickiego wśród młodzieży zwłaszcza poprzez katechizację i organizowanie letniego wypoczynku - w tym okresie ok. 95\% uczniów całego województwa brało udział w katechezie. Poza tym Wydział zwracał uwagę na rozwój ruchu oazowego w Krośnieńskiem - zarówno w formie letnich obozów, w których w roku 1987 uczestniczyło w województwie łącznie 3000 osób pozostających pod opieką 35 księży, 2 wychowawców świeckich i 4 kleryków, jak i stałej działalności przy parafiach. Jednocześnie J. Chlebuś wskazywał, że ówczesna liberalizacja przepisów meldunkowych pozbawiła Wydział możliwości skutecznego ograniczania wakacyjnych oaz ${ }^{66}$. 11 czerwca 1980 roku pracownicy krośnieńskiej administracji wyznaniowej przedstawili innym jednostkom województwa wytyczne Urzędu do Spraw Wyznań dotyczące oaz. Przede wszystkim w sytuacji domniemania jakichkolwiek uchybień z zakresu regulacji sanitarnych, czy przeciwpożarowych zalecano kierować kontrole właściwych jednostek wraz z przedstawicielami kuratorium oświaty. Jednak zakazano dokonywać ich w obecności umundurowanych funkcjonariuszy MO, a „rozwiązanie oazy" mogło nastąpić jedynie po konsultacji z władzami centralnymi w Warszawie ${ }^{67}$. Jak widać, wytyczne te jednoznacznie rekomendowały prowadzenie bardziej ,dyskretnych” form realizacji założeń polityki wyznaniowej, bez podejmowania działań mogących narazić władze komunistyczne na otwarty konflikt z miejscową ludnością.

Jedną z cech polityki wyznaniowej Polski Ludowej była próba przeprowadzenia pełnej laicyzacji społeczeństwa poprzez lansowanie świeckiej symboliki, obrzędowości i kultury ${ }^{68}$. W dokumentach

${ }^{65}$ Materiaty na Wojewódzka Konferencję Sprawozdawczo-Wyborcza, (KW PZPR, Krosno 1978): 24, 36-37.

${ }^{66}$ Informacja dot. oddziaływania kościoła rzymskokatolickiego na młodzież, IPN-Rz-62/145, k. 1-3; Zob. Informacja dot. ruchu oazowego w woj. krośnieńskim, IPN-Rz-62/138, k. 3-4.

${ }^{67}$ Informacja nt. „Ruchu Światło-Życie”/grup oazowych/, IPN-Rz-62/138, k. 33-36.

${ }^{68}$ Barbara Rogowska, Polityka polskich władz komunistycznych wobec Kościoła rzymskokatolickiego (Wrocław: Wydawnictwo Uniwersytetu Wrocławskiego, 2013), 131-132. 
Urzędu do Spraw Wyznań można spotkać twierdzenia, że świeckość Państwa Ludowego jest elementem jego porządku konstytucyjnego, stąd obowiązek jej poszanowania dotyczy wszystkich obywateli, stąd np. żądania umieszczenia krzyży w miejscach publicznych uznano za przejaw klerykalizacji ${ }^{69}$. W 1980 roku w 100 szkołach na łączną liczbę 468 szkół województwa krośnieńskiego zawieszono krzyże ${ }^{70}$, natomiast w 1988 roku znajdowały się one w 95\% szkół ${ }^{71}$. W tym samym roku A. Merker wyjaśniał wszystkim jednostkom administracji wyznaniowej, że zakaz umieszczania krzyży w szkołach wynika z zasady świeckiego charakteru szkoły będącej realizacją konstytucyjnego modelu rozdziału kościoła od państwa, stąd w przypadku naruszenia tego zakazu władze województwa powinny interweniować podejmując rozmowy z przedstawicielami kurii diecezjalnych ${ }^{72}$. Powoływanie się na zasadę rozdziału było głównym argumentem władz krośnieńskiego na odmowę wyrażenia zgody na naukę religii w salach szkolnych ${ }^{73}$, jednocześnie wskazywano na potrzebę konsekwentnego postępowania w tych kwestiach, aby nie tworzyć żadnych precedensów w „ochronie szkoły przed wprowadzeniem do niej nauki religii"74.

Dla krośnieńskiego Wydziału realizacja konstytucyjnych zasad relacji pomiędzy państwem a związkami wyznaniowymi oznaczała pełną laicyzację życia społecznego ${ }^{75}$. Przykładem takiego stanu rzeczy

${ }^{69}$ Uwagi na temat broszury zatytułowanej ,, Szkoła polska czy ateistyczna? Uwagi do rodziców” z 9.05.1988 roku, IPN-Rz-62/139, k. 280.

${ }^{70}$ Wykaz szkól w których zawieszono emblematy religijne na dzień 14 listopada $1980 \mathrm{r}$., IPN-Rz-62/53, k. 212-217.

${ }^{71}$ Informacja dot. oddziaływania kościoła rzymskokatolickiego na młodzież, IPN-Rz62/145, k. 1 .

${ }^{72}$ Pismo V-Dyrektora Urzędu do Spraw Wyznań z dnia 10 listopada 1980 r., IPN-Rz62/53, k. 69; Pismo Ministra Kierownika Urzędu do Spraw Wyznań do tow. Tadeusza Kruka Wojewody Krośnieńskiego, IPN-Rz-62/53, k. 71.

${ }^{73}$ Pismo do Komitetu Rodzicielskiego przy Zbiorczej Szkole Gminnej w Tyrawie Wołoskiej, IPN-Rz-62/53, k. 90; Pismo do księdza Karola Adamowicza, IPN-Rz-62/53, k. 100;

${ }^{74}$ Opinia Wydziału do Spraw Wyznań Urzędu Wojewódzkiego w Krośnie dot. wniosku o przekazanie pomieszczeń szkolnych $w$ Zawadce Rymanowskiej $k$. Rymanowa na cele katechetyczne i mieszkalne Księdza, IPN-Rz-62/53, k. 102.

${ }^{75}$ Zob. Problemy w sprawie opracowania harmonogramu laicyzacji życia społecznego w województwie do omówienia na naradzie, IPN-Rz-62/7, k. 28; Informacja dot. świeckiego wychowania i obrzędowości z 20 lipca 1987 roku, IPN-Rz-62/7, k. 29. 
jest „Program kształtowania kultury świeckiej” przygotowany przez Urząd do Spraw Wyznań w 1986 roku. W dokumencie tym świeckość instytucji państwowych uznano za warunek zapewnienia wolności sumienia i wyznania, tolerancji i zbudowania praworządnego społeczeństwa. Jednocześnie zaplanowano w celu realizacji konstytucyjnej zasady rozdziału m.in. ,umacnianie laickich postaw nauczycieli i wychowawców”, „rozwijanie świeckiego ceremoniału szkolnego”, „systematyczną krytykę klerykalizmu w środkach masowego przekazu” oraz „wzrost rangi świeckich ceremoniałów obywatelskich: uroczystego nadania imienia dziecku, ślubu cywilnego, świeckiego pogrzebu"76. Realizując ten plan krośnieńska administracja wyznaniowa planowała bezpłatnie udostępniać młodzieży obiekty sportowe i organizować atrakcyjne rozgrywki w godzinach sprawowania mszy św., zwiększyć wydatki na wystrój urzędów stanu cywilnego i zatrudnić na terenie województwa „Świeckich mistrzów ceremonii pogrzebowej”. W planie tym uwzględniono także wytyczne w ramach ,przestrzegania konstytucyjnych zasad wolności sumienia i wyznania oraz świeckiego charakteru placówek państwowych". Do tej kategorii zaliczono takie działania, jak: uaktualnienie regulaminu czasu i form pracy kapelanów szpitalnych, przeciwdziałanie zakłóceniu spokoju w szpitalach np. przez zbiorowe śpiewy, działania na rzecz świeckiego wystroju obiektów i placówek państwowych oraz środków transportu, egzekwowanie przepisów w sprawie organizacji punktów katechetycznych ${ }^{77}$. W kwietniu 1986 roku dyrektor krośnieńskiego Wydziału J. Chlebuś przedkładając informacje z zakresu działań laicyzacyjnych stwierdził, że ma ona na celu „pełne przestrzeganie konstytucyjnych zasad wolności sumienia i wyznania i rozdziału kościoła od państwa". W tym zakresie Wydział ściśle współpracował ze strukturami bezpieczeństwa i aktywem partyjnym oraz kuratorium oświaty. W swoim sprawozdaniu zwrócił uwagę na ważniejsze przejawy realizacji tychże celów w pracy Wydziału: organizowanie szkoleń

${ }^{76}$ Program ksztaltowania kultury świeckiej, AAN zespół 1587, sygn. 126/13, k. 70-71, 73, 80, 74, 78 .

${ }^{77}$ Program działania Urzędu Wojewódzkiego $w$ zakresie świeckiego wychowania i obrzędowości, IPN-Rz-62/7, k. 21-26; Pismo z dnia 19 marca 1986 roku do Obywatela Dyrektora Wydziału ds. Wyznań w Krośnie, IPN-Rz-62/7, k. 47. 
z zakresu polityki wyznaniowej i stosunków państwo-Kościół podczas konferencji nauczycielskich, czy dla pracowników Urzędu Wojewódzkiego, oddziaływanie na świeckich i duchowieństwo (zwłaszcza księży nieprzestrzegających zasad konstytucyjnych) poprzez „rozmowy lojalizujące". Rozmowy te prowadzono zarówno przez pracowników Wydziału jak i innych jednostek administracji ${ }^{78}$.

W sprawozdaniach przesyłanych do Urzędu do Spraw Wyznań przez terenowe organy rozmowy z duchowieństwem określano jako podstawową formą oddziaływania administracji wyznaniowej na duchowieństwo w kierunku jego lojalizacji, a sprawy wnoszone przez „księży lojalnych” były załatwiane w pierwszej kolejności ${ }^{79}$. Jednocześnie duchowni ,znani z braku lojalizmu i skłonności do naruszania prawa" najczęściej spotykali się z decyzjami odmownymi ${ }^{80}$. Celem tych rozmów było wyrobienie w duchowych przekonania, że ,jedyna słuszna i korzystna dla nich droga to przestrzeganie obowiązującego prawa"81. Krośnieński Wydział za cel przeprowadzania rozmów z duchownymi uznawał uzyskanie ich poparcia dla polityki PRL oraz dezaprobaty dla negatywnych wystąpień hierarchii Kościoła Rzymskokatolickiego. Stąd też podczas rozmów należało wskazywać na rozwój gospodarczy PRL, zwiększenie się stanu posiadania Kościoła, funkcjonowanie uczelni katolickich oraz wyrazić uznanie lub dezaprobatę wobec stanowiska duchownego w stosunku do tych kwestii. Księżom znanym z wrogiej postawy należało zwrócić uwagę na „nieracjonalność” ich postępowania ${ }^{82}$.

${ }^{78}$ Informacja dotyczaca działania Wydziału do Spraw Wyznań $w$ zakresie laicyzacji życia społecznego, IPN-Rz-62/7, k. 27.

${ }^{79}$ Sprawozdanie z pracy Wydziału do Spraw Wyznań Urzędu Miasta Warszawy za okres od 1.IX.1975 do 1.IX.1977, AAN, zespół 1587, sygn. 127/67, k.3-6; Syntetyczna charakterystyka $i$ ocena wyników polityki wyznaniowej na terenie województwa białostockiego 1.IX.1975-1.IX.1977, AAN, zespół 1587, sygn. 127/67, k.14-16;

${ }^{80}$ Informacja o realizacji zadań w zakresie polityki wyznaniowej, AAN, zespół 1587, sygn. 127/67, k. 29; Charakterystyka i ocena polityki wyznaniowej na terenie województwa kaliskiego w okresie 1.09.1975-1.09.1977, AAN, zespół 1587, sygn. 127/67, k.81-85; Charakterystyka i ocena wyników polityki wyznaniowej w okresie od 1 września 1975 do 1 września 1977, AAN, zespół 1587, sygn. 127/67, k. 97-91.

${ }^{81}$ Ocena wyników realizacji polityki wyznaniowej $w$ województwie częstochowskim za okres 1.IX.1975-1.IX.1977, AAN, zespół 1587, sygn. 127/67, k. 53.

${ }^{82}$ Tezy dla naczelników miast i gmin do rozmów z duchowieństwem rzymsko-katolickim, IPN-Rz-62/125, k. 14-16; Tezy dla przewodniczacych miejskich $i$ gminnych rad narodo- 


\section{PROBLEMATYKA BUDOWNICTWA SAKRALNEGO I KOŚCIELNEGO}

Zgodnie ze sprawozdaniem złożonym przez dyrektora krośnieńskiego Wydziału do Spraw Wyznań W. Serwatkę kwestia budownictwa sakralnego była podstawowym zagadnieniem polityki wyznaniowej województwa. Obszar krośnieńskiego w zdecydowanej większości należał do diecezji przemyskiej obrządku łacińskiego, której przewodził w tamtym czasie bp Ignacy Tokarczuk. W historiografii zapisał się on jako inicjator niespotykanej w skali całego kraju akcji nielegalnego budownictwa sakralnego. Stąd też przeciwdziałanie rozrostowi zaplecza materialnego Kościoła Katolickiego wymagało podjęcia bardziej skomplikowanych działań angażujących zarówno Wydział, jak i rozbudowujące się na tym terenie w drugiej połowie lat siedemdziesiątych struktury bezpieczeństwa ${ }^{83}$, czy jednostki Polskiej Zjednoczonej Partii Robotniczej. Już na samym początku istnienia województwa raportowano, że duchowni dążąc do wznoszenia nowych świątyń angażują w tą działalność spore grupy wiernych „wytwarzając psychozę zagrożenia kościoła i jego swobód”. Wznoszenie kościołów, czy innych obiektów sakralnych wbrew sprzeciwom władz uznano za „szkodliwe politycznie i społecznie"84. W województwie krośnieńskim Wydział ściśle współpracował w tym zakresie ze strukturami bezpieczeństwa oraz PZPR określając poczynania bp. Tokarczuka, jako wzniecanie waśni społecznych oraz ,,angażowanie duchowieństwa w naruszanie stanowionego przez Państwo porządku prawnego". Jednocześnie decyzje o udzieleniu pozwolenia na prowadzenie inwestycji budowlanych zapadały na szczeblu politycznym, po konsultacji z władzami Komitetu Wojewódzkiego PZPR ${ }^{85}$. Do najczęściej podejmowanych

wych oraz Naczelników miast $i$ gmin do rozmów z duchowieństwem rzymsko-katolickim województwa krośnieńskiego, IPN-Rz-62/106, k. 2-3.

${ }^{83}$ Dariusz Iwaneczko twierdzi, że rozwój wydziałów IV KWMO na terenie województw Polski południowo-wschodniej w drugiej połowie lat siedemdziesiątych wiązał się z aktywnością bp. Ignacego Tokarczuka, zob. Tenże, Zmierzch dekady Gierka. Polska potudniowo-wschodnia 1975-1980 (Rzeszów: Instytut Pamięci Narodowej Komisja Ścigania Zbrodni przeciwko Narodowi Polskiemu oddział w Rzeszowie, 2016), 130.

${ }^{84}$ Informacja o stanie posiadania i działalności kościoła rzymskokatolickiego na terenie województwa krośnieńskiego, IPN-Rz-62/139, k. 3.

${ }^{85}$ Pismo Urzędu Wojewódzkiego w Krośnie do Urzędu do Spraw Wyznań w Warszawie z 28 września 1977 r., AAN, zespół 1587, sygn. 127/67, k. 119-120. 
działań przeciwko budownictwu sakralnemu zaliczano przeprowadzanie „rozmów ostrzegawczych” z duszpasterzami i wiernymi podejmującymi nielegalne budownictwo przez pracowników Wydziału, funkcjonariuszy Służby Bezpieczeństwa, czy dyrektorów zakładów pracy; odciągnięcie mieszkańców od budowy obiektów sakralnych poprzez ich aktywizację w czynach społecznych; prowadzanie działalności „neutralizujących” budowę za pośrednictwem członków PZPR; wznoszenie innych budynków w okolicy mającego powstać kościoła (np. w miejscowości Rzepedź zainicjowano budowę zajazdu turystycznego); prowadzenie działalności operacyjnej przez organy bezpieczeństwa celem wczesnego rozpoznania zamiarów budowalnych. Poza tym dostrzegano potrzebę „otoczenia specjalną opieką" księży wykazujących pozytywny stosunek do PRL, np. poprzez udzielanie im zapomóg. Czynnikiem hamującym podejmowanie nielegalnych budów miało być wydawanie zgód na kilka inwestycji każdego roku, tak aby móc przedstawić je jako argument uzasadniający bezzasadność żądań Kościoła. Przykładowo w latach 1975-1979 wydano 30 zezwoleń na wzniesienie budynków sakralnych i kościelnych ${ }^{86}$. Jednak w przypadku, gdy działania te nie przynosiły rezultatu i nie było „realnych szans odciągnięcia ludności od budowy kościoła” Wydział rekomendował udzielenie na nią zezwolenia ${ }^{87}$.

Szczególnym problemem była dla władz niemożliwość skutecznego wyegzekwowania przestrzegania obowiązujących w tej materii przepisów prawa poprzez silny opór ludności. Jednym z wielu przykładów takiego stanu rzeczy jest bezradność władz krośnieńskiego wobec zajęcia przez mieszkańców miejscowości Krzemienna i Obarzyn budynków na punkty katechetyczne. Mieszkańcy wymienili wszystkie zamki w zajętych budynkach, co uniemożliwiło interwencję władz ${ }^{88}$.

${ }^{86}$ Informacja o stanie posiadania i działalności kościoła rzymskokatolickiego na terenie województwa krośnieńskiego, IPN-Rz-62/139, k. 5-6; Wykaz wydanych zezwoleń na obiekty sakralne i kościelne na terenie woj. krośnieńskiego w latach 1975-1979, IPN-Rz-62/46, k. 1-5.

${ }^{87}$ Informacja o rozwoju sytuacji $w$ zakresie nielegalnego budownictwa sakralnego w województwie krośnieńskim, IPN-Rz-62/64, k. 103-109, Notatka stużbowa dot. osób aktywnie zaangażowanych przy organizowaniu samowolnego obiektu sakralnego i punktu katechetycznego w Ustrzykach Dolnych, IPN-Rz-62/64, k. 116.

${ }^{88}$ Notatka z przeprowadzonej dnia 11 października 1979 r. rozmowy z Naczelnikiem Gminy w Dydni na temat sytuacji zwiazanej z nielegalnym budownictwem lub adaptacja budynków na punkty katechetyczne na terenie gminy, IPN-Rz-62/87, k. 2. 
Ciekawym przypadkiem jest także sprawa ukarania ks. Józefa Pruchnickiego za nielegalne zorganizowanie zgromadzenia w Domu Ludowym w Wawrze poprzez odprawienie w nim mszy św. Co ciekawe w miejscowości tej znajdowała się kaplica, jednak zbyt mała dla pomieszczenia wszystkich chętnych, stąd duchowny wraz z grupą ok. 300 wiernych po zgromadzeniu się przy niej przeszli do Domu Ludowego ${ }^{89}$.

Czytelnym przykładem polityki laicyzacyjnej władz województwa krośnieńskiego jest sprawa konfliktu wokół cerkwi greckokatolickiej w Ustrzykach Dolnych, którą chciał zagospodarować proboszcz miejscowej parafii rzymskokatolickiej. Po przejęciu jej przez Skarb Państwa od 1956 roku była ona dzierżawiona przez Gminną Spółdzielnię na magazyn. W 1972 roku Prezydium Powiatowej Rady Narodowej w Ustrzykach Dolnych chcąc nie dopuścić do przejęcia tego obiektu przez parafię rzymskokatolicką wystąpiło z wnioskiem do Wojewódzkiej Rady Narodowej w Rzeszowie o adaptację cerkwi na cele gospodarcze. Wojewódzka Rada wyraziła na to zgodę 23 lutego 1972 roku $^{90}$. Przeszło dwa lata po tym wydarzeniu - 10 września 1974 roku Wydział Gospodarki Komunalnej, Przestrzennej, Ochrony Środowiska i Komunikacji Urzędu Powiatowego w Lesku wystąpił z wnioskiem do Wojewódzkiego Konserwatora Zabytków o pozwolenie na rozbiórkę cerkwi uzasadniając to złym stanem technicznym budynku. Jednak ze względu na niedopełnienie wymagań formalnych nie nadano dalszego biegu wnioskowi ${ }^{91}$. Pomimo tego parafia rzymskokatolicka w Ustrzykach Dolnych nie ustawała w swoich staraniach o przejęcie cerkwi. 22 marca 1975 roku skierowała w tej sprawie pismo do Powiatowego Urzędu Bieszczadzkiego w Lesku, a po dwuletniej bezczynności organu zwróciła się do wojewody krośnieńskiego o podjęcie interwencji $\mathrm{w}$ tej sprawie wskazując na zaniechania władz prowadzące budynek do zniszczenia ${ }^{92}$. Niestety wojewoda

${ }^{89}$ Wniosek o ukaranie, IPN-Rz-62/37, k. 3, Notatka urzędowa, IPN-Rz-62/37, k. 4.

${ }^{90}$ Informacja o zabytkowej cerkwi w Ustrzykach Dolnych pow. bieszczadzki, IPN-Rz62/64, k. 16 .

${ }^{91}$ Informacja o zabytkowej cerkwi w Ustrzykach Dolnych pow. bieszczadzki, IPN-Rz62/64, k. 16-17.

${ }_{92}$ Pismo z dnia 14.04.1977 roku do Wojewody Krośnieńskiego Pana Wojciecha Grochali, IPN-Rz-62/64, k. 18-19. 
krośnieński również nie zajął stanowiska w tej kwestii w związku z czym proboszcz parafii w Ustrzykach skierował 6 lutego 1978 r. pismo do Wydziału do Spraw Wyznań w Krośnie ${ }^{93}$. Poza tym czerwcu 1977 roku na terenie województwa krośnieńskiego odbyła się komisja konserwatorska Ministerstwa Kultury i Sztuki, która rekomendowała skreślenie przedmiotowej cerkwi z ewidencji zabytków i przekazanie jej do kompetencji władz lokalnych ${ }^{94}$.

Z pewnością już od czerwca 1978 roku trwały prace nad przekazaniem budynku cerkwi na „,cele kulturalno-oświatowe” jako filię Muzeum Budownictwa Ludowego w Sanoku urządzając wystawy sztuki ludowej oraz prac powstałych podczas bieszczadzkich plenerów malarskich ${ }^{95}$. Działania w zakresie przejęcia budynku cerkwi prowadził Wojewódzki Konserwator Zabytków po uzgodnieniu z Wydziałem do Spraw Wyznań. Harmonogram prac został przesłany Naczelnikowi Miasta i Gminy w Ustrzykach Dolnych 27 lipca 1978 roku $^{96}$. O podjęciu decyzji co do zagospodarowania cerkwi na cele kulturalne Wydział do Spraw Wyznań poinformował proboszcza parafii w Ustrzykach Dolnych 28 lipca 1978 roku ${ }^{97}$, chociaż formalna decyzja w tej sprawie zapadła dopiero 2 listopada tego roku ${ }^{98}$. Po otrzymaniu tej informacji ks. proboszcz Stanisław Matuła skierował pismo do Wojewódzkiej Rady Narodowej - podpisane przez kilkaset osób - po raz kolejny prosząc o przekazanie cerkwi na rzecz parafii i zapewniając o podjęciu koniecznych prac remontowych ${ }^{99}$.

${ }^{93}$ Pismo z dnia 6.02.1978 roku do Wojewódzkiego Wydziału Wyznań w Krośnie, IPN-Rz62/64, k. 22-23.

${ }^{94}$ Poufna informacja nt. działalności Komisji Konserwatorskiej Ministerstwa Kultury i Sztuki na terenie województwa krośnieńskiego 14-16.06.1977, IPN-Rz-62/64, k. 20-21.

${ }^{95}$ Opinia na temat zagospodarowania zabytkowej cerkwi $w$ Ustrzykach Dolnych woj. krośnieńskie, IPN-Rz-62/64, k. 25-26.

${ }^{96}$ Pismo z dnia 27 lipca 1978 roku do obywatela Naczelnika Miasta i Gminy w Ustrzykach Dolnych, IPN-Rz-62/64, k. 27, Adaptacja d. cerkwi w Ustrzykach Dolnych na cele kulturalno-oświatowe. Harmonogram działań, IPN-Rz-62/64, k. 28-29.

${ }^{97}$ Pismo z dnia 28 lipca 1978 roku do ks. Stanisława Matuly Proboszcza Parafii Rzymsko-Katolickiej w Ustrzykach Dolnych, IPN-Rz-62/64, k. 24.

${ }^{98}$ Decyzja Naczelnika Miasta i Gminy w Ustrzykach Dolnych z dnia 2 listopada 1978 roku, IPN-Rz-62/64 k. 60-61.

${ }^{99}$ Pismo z dnia 26 sierpnia 1978 roku do Przewodniczacego Wojewódzkiej Rady Narodowej w Krośnie, IPN-Rz-62/64, k. 35-59 
Dzień po formalnym podjęciu decyzji swoje odwołanie wniosła także Kuria Diecezjalna w Przemyśllu ${ }^{100}$.

Pomimo nieugiętej postawy władz ks. Matuła, jak i władze diecezjalne w Przemyślu kontynuowały starania o odzyskanie cerkwi. Krośnieński Wydział do Spraw Wyznań monitorując treści kazań bp. Tokarczuka zwracał uwagę, że często wskazuje on na potrzebę budowy nowego kościoła w Ustrzykach w sytuacji, gdy władze nie pozwolą na przejęcie cerkwi. Jednocześnie Biskup Przemyski zapowiadał, że w przypadku braku zezwolenia na budowę świątynia powstanie nielegalnie. W wyniku działań operacyjnych władze dowiedziały się, iż ks. Matuła planuje po „pasterce” 1978 roku urządzić procesję do cerkwi i odprawić tam nabożeństwo w intencji jej odzyskania. Aby nie dopuścić do realizacji tych zamierzeń Wydział postanowił przeprowadzić „rozmowę profilaktyczno-ostrzegawczą” z ks. Matułą przez „kompetentne osoby z urzędu wojewódzkiego”, a Naczelnikowi Miasta i Gminy polecono przeprowadzenie analogicznych rozmów z mieszkańcami zaangażowanymi w sprawę. Jednocześnie zobowiązano dyrekcję Muzeum Budownictwa Ludowego w Sanoku do zabezpieczenia drzwi świątyni i przyspieszenia remontu. $Z$ adnotacji zamieszczonej na dokumencie wynika, że rozmowę z ks. Matułą przeprowadził sam wojewoda krośnieński 22 grudnia 1978 roku $^{101}$. Kilka dni wcześniej ks. Matuła przesłał do WdSW w Krośnie pismo, w którym po raz kolejny wnioskował o zwrot cerkwi, ewentualnie o wyrażenie zgody na budowę nowego kościoła zapowiadając podjęcie nielegalnej budowy w razie decyzji odmownej. W końcu we wrześniu 1979 roku ks. Matuła - przy dużym poparciu parafian - nielegalnie zaadaptował dom Romana Korczaka na kaplicę i punkt katechetyczny.

Właściciel tej nieruchomości nabył ją w 1978 roku w drodze spadkobrania po swoich rodzicach. Zamiar zaadaptowania domu na kaplicę oraz wybudowania kościoła na tej nieruchomości był znany organom władzy, które poprzez „rozmowy profilaktyczne” starały się przeciw-

${ }^{100}$ Pismo z dnia 3 listopada 1978 roku do Pana Wojewody Krośnieńskiego Stanisława Szczepańskiego, IPN-Rz-62/64, k. 62-

${ }^{101}$ Informacja z dnia 20 grudnia 1978 roku dot. sytuacji w parafii Ustrzyki Dolne, IPN-Rz-62/64, k. 71-76. 
działać realizacji tych celów. Poza tym Naczelnik Miasta i Gminy uznał gospodarstwo R. Korczaka za zaniedbane i na podstawie rozporządzenia z dnia 26 marca 1968 roku w sprawie zaliczania gospodarstw rolnych do kategorii wykazujących niski poziom produkcji ${ }^{102}$ orzekł o przejęciu go na własność Skarbu Państwa. Po odwołaniu Decyzja ta została uchylona i przekazana do ponownego rozpoznania. W związku z tym Naczelnik nakazał zagospodarowanie gruntu i budynku oraz doprowadzenie gospodarstwa do pełnej produktywności do 31 lipca 1980 roku jednocześnie oferując właścicielowi wykup jego nieruchomości na rzecz Skarbu Państwa. Ten jednak nie przyjął tej propozycji i zawarł z ks. Matułą nieformalną umowę sprzedaży nieruchomości. W tej sytuacji Naczelnik Miasta i Gminy Ustrzyki Dolne w obecności dyrektora jego zakładu pracy oraz sekretarza Podstawowej Organizacji Partyjnej przeprowadził z R. Korczakiem rozmowę ponownie proponując zakup nieruchomości na rzecz Skarbu Państwa oraz informując o grążących skutkach nieprawnego działania. R. Korczak ponownie odmówił, w wyniku czego postanowiono wyciągnąć wobec niego konsekwencje.

Otóż R. Korczak wraz z rodziną mieszkał od 1966 roku w mieszkaniu służbowym Zarządu Budownictwa Leśnego, gdzie pracował. Wobec tego stwierdzono, że skoro posiada własny dom lokal ten mu nie przysługuje. Z wnioskiem o pozbawienie R. Korczaka lokalu służbowego wystąpił Naczelnik Miasta i Gminy Ustrzyki Dolne. Wniosek ten został złożony 25 września 1979 roku, a więc dzień po zawarciu umowy z ks. Matułą, i rozpatrzony jeszcze tego samego dnia ${ }^{103}$. W wyniku decyzji dyrektora ZBL R. Korczak został pozbawiony lokalu służbowego. Decyzja ta została zatwierdzona 11 października tegoż roku ${ }^{104}$. Jednocześnie Naczelnik na podstawie przepisów prawa lokalo-

${ }^{102}$ Dz. U. z 1968 r. Nr 11, poz. 58.

${ }^{103}$ Pismo z dnia 25 września 1979 roku do Obywatela Dyrektora Zarząu Budownictwa Leśnego w Ustrzykach Dolnych, IPN-Rz-62/64, k. 111; Pismo z dnia 25 września 1979 roku do Romana Korczaka, IPN-Rz-62/64, k. 112.

${ }^{104}$ Pismo z dnia 1 października 1979 roku do Wojewody Krośnieńskiego, IPN-Rz-62/64, k. 115; Pismo do ob. Romana Korczaka z dnia 11 października 1979 roku, IPN-Rz-62/64, k. 125; Odwołanie do Obywatela Ministra Administracji Gospodarki Terenowej i Ochrony Środowiska, IPN-Rz-62/64, k. 126. 
wego zabezpieczył plombami budynek, który planowano rozbudować na kaplicę. Pomimo tego 27 września ks. Matuła wraz z wiernymi dokonał zerwania plomb, a następnie celebrował nabożeństwo i rozpoczął regularną naukę religii. Próbując przeciwdziałać rozbudowie domu 2 października Naczelnik Miasta i Gminy wydał decyzję zakazującą wszelkich prac budowalnych na tej nieruchomości. W tym okresie ks. Matuła dwukrotnie - 25 września i 16 października - był wzywany do WdSW w Krośnie, gdzie przedstawiano mu grożące konsekwencje za jego działalność ${ }^{105}$.

W związku z inicjatywą nielegalnej budowy oraz wpływającymi pod koniec 1979 roku petycjami mieszkańców żądającymi udzielenia zezwolenia na wzniesienie kościoła Wydział proponował m.in.: zorganizowanie spotkania z mieszkańcami osiedla PCK, gdzie miałaby stanąć świątynia, podczas którego poinformowano by o planach budowy na tym terenie obiektów usługowo-gospodarczych; prowadzenie działań dezintegracyjnych w środowisku oraz odpowiednią zmianę miejscowego planu zagospodarowania przestrzennego w rejonie nielegalnej kaplicy ${ }^{106}$, tak aby uniemożliwić wydanie zezwolenia na tego typu budowę. Po dokonaniu tych ustaleń i przeprowadzeniu wizji lokalnej 31 stycznia 1979 roku kierownik krośnieńskiego Wydziału zwrócił się do ks. Matuły z pismem, w którym informował, że podjęcie decyzji co do budowy kościoła napotyka na trudności związane $\mathrm{z}$ realizacją planu zagospodarowania przestrzennego ${ }^{107}$. Odpowiadając na pismo ks. proboszcz wskazał, że podczas przedmiotowej wizji lokalnej, w której uczestniczył wojewoda i kierownik WdSW otrzymał ustne zapewnienie o wyrażeniu zgody na budowę kościoła w styczniu 1979 roku $^{108}$. Podczas niej przedstawiciele władz zaproponowali rozbudowę istnie-

${ }^{105}$ Informacja o nielegalnym budownictwie sakralno-kościelnym w Ustrzykach Dolnych, IPN-Rz-62/64, k. 128-133.

${ }^{106}$ Informacja o czynnościach - staraniach przez kler $w$ zakresie uzyskania dla potrzeb kultu religijnego obiektu pocerkiewnego i podejmowanych działaniach przez ks. Matułe w zwiąku z dokonana adaptacją budynku na kaplicę w Ustrzykach Dolnych, IPN-Rz-62/64, k. 81-85.

${ }^{107}$ Pismo do ks. Stanisława Matuly Proboszcza Parafii Rzymsko-Katolickiej w Ustrzykach Dolnych z dnia 31 stycznia 1979 roku, IPN-Rz-62/64, k. 87.

${ }^{108}$ Pismo z dnia 14 lutego 1979 roku do Urzędu Wojewódzkiego Wydziału do Spraw Wyznań w Krośnie, IPN-Rz-62/64, k. 90-91. 
jącej kaplicy w Strwiążku na terenie przeznaczonym na budowę infrastruktury turystycznej, oddalonym o ok. 1,5-2,5 km od osiedla PCK. $\mathrm{Z}$ tych względów proboszcz i parafianie odmówili przeprowadzenia tej inwestycji. Wydział do Spraw Wyznań w związku z fiaskiem podejmowanych ,działań polityczno-administracyjnych i operacyjnych” proponował rozważenie przekazania cerkwi na rzecz parafii lub przeznaczenie działki na terenie Ustrzyk Dolnych na budowę kościoła. Ciekawym jest, że motywując pierwszą z propozycji Urząd wskazał, że jej realizacja odciążyła by Skarb Państwa z kosztów remontu oraz ,pozbawiła by kler i wiernych argumentów o jej niewłaściwym użytkowaniu”"109.

Ks. Matuła w 1979 roku podjął także starania o zakup części działki Zakładu Handlu w Ustrzykach należącego do Wojewódzkiego Związku Spółdzielni Rolniczych „Samopomoc chłopska” w Krośnie z myślą o wzniesieniu na niej budynku gospodarczego dla parafii. Jednak Zakład ten odmówił przekazania nieruchomości na rzecz Gminy, która następnie miała przekazać ją parafii. Dokumentacja tej sprawy dostarcza ciekawych informacji nt. metod działania krośnieńskiej administracji wyznaniowej. Otóż pozwolenie na budowę zostało wydane przez Naczelnika Miasta i Gminy Ustrzyki Dolne po uzgodnieniu z Wydziałem do Spraw Wyznań. Wobec braku zgody władz Spółdzielni na przekazanie działki kierownik Wydziału zwrócił się do jej prezesa z prośbą o „spowodowanie” przekazania działki ze względu na ,celowość wydania zezwolenia na budowę budynku gospodarczego dla parafii w Ustrzykach Dolnych"110.

Innym ciekawym przykładem realizowania polityki wyznaniowej w zakresie budownictwa sakralnego przez krośnieńską administrację wyznaniową jest sprawa budowy kaplicy w Jaszczwi (parafia Szebnie). Po raz pierwszy nabożeństwo w punkcie katechetycznym zlokalizowanym w domu Emila Przybyły w Jaszczwi zostało odprawione 17 listopada 1974 roku przez ks. Józefa Opiołę. Pierwotnie w pomieszcze-

109 Tajna informacja z dnia 15 marca 1979 roku dot. sytuacji w parafii Ustrzyki Dolnej, IPN-Rz-62/64, k. 95-99.

${ }^{110}$ Pismo z dnia 27 sierpnia 1979 roku do Obywatela Prezesa Wojewódzkiego Zwiazku Rolniczych Spółdzielni „Samopomoc Chłopska” w Krośnie, IPN-Rz-62/64, k. 101; Pismo z dnia 25 czerwca 1979 roku do Parafii Rzymsko-Katolickiej w Ustrzykach Dolnych, IPN-Rz-62/64, k. 100. 
niu tym mieścił się Urząd Pocztowy. Mieszkańcy miejscowości nosili się z zamiarem odkupienia budynku i jego rozbudowy z przeznaczeniem na kaplicę. Władze wojewódzkie spodziewały się - ze względu na nikłe wpływy PZPR w tej miejscowości - silnego oporu mieszkańców przeciwko udaremnieniu tych planów. Stąd pierwszym pomysłem, wysuniętym przez Naczelnika Gminy Jedlicze, było zorganizowanie na pobliskiej do punktu katechetycznego nieruchomości kółka rolniczego Grupy Robót Drogowych, stanowiącego filię Rejonu Eksploatacji Dróg Publicznych w Jaśle, a także przeznaczenie budynku Emila Przybyły na biura tego przedsiębiorstwa. Jednak pomysł ten nie spotkał się z akceptacją Wojewódzkiego Zarządu Kółek Rolniczych ${ }^{111}$. W związku z tym administracja wyznaniowa wraz z Komitetem Wojewódzkim PZPR zaproponowały rozbudowę bazy kółka rolniczego lub zakup domu Emila Przybyły przez Gminę Jedlicze na cele społeczne. Ostatecznie przystano na pierwszy pomysł planując poszerzenie terenu należącego do kółka rolniczego w związku z budową Terenowej Stacji Obsługi Sprzętu Rolniczego ${ }^{112}$. Wobec tych planów mieszkańcy przystąpili do rozbudowy punktu katechetycznego. Po rozpoczęciu prac Naczelnik Gminy wydał decyzję nakazującą natychmiastowe wstrzymanie budowy $^{113}$, a kilka dni później rozbiórkę budynku. Naczelnik zwrócił się także do Prokuratora Rejonowego o wszczęcie postępowania karnego wobec ks. Józefa Opioły i mieszkańców zaangażowanych w budowę ${ }^{114}$.

Mieszkańcy podjęli także próbę wzniesienia kaplicy pod pozorem budowy prywatnych budynków przez dwóch mieszkańców Jaszczwi, jednak Naczelnik Gminy Jedlicze wydał wobec nich decyzję o natychmiastowym zaprzestaniu budowy i przejęciu na własność państwa wzniesionych elementów ${ }^{115}$. Jeden $\mathrm{z}$ nich odwołał się do Ministra Administracji, Gospodarki Terenowej i Ochrony Środowiska, który negatywnie odniósł się do działań administracji gminnej, nakazał

${ }^{111}$ Informacja dot. sytuacji w Jaszczwi, IPN-Rz-62/33, k. 1-2.

${ }^{112}$ Pismo do Urzędu Miasta i Gminy Jedlicze, IPN-Rz-62/33, k. 18.

${ }^{113}$ Decyzja Naczelnika Miasta i Gminy Jedlicze z 3 sierpnia 1978 r., IPN-Rz-62/33, k. 26.

${ }^{114}$ Pismo do Prokuratora Rejonowego w Krośnie, IPN-Rz-62/33, k. 30.

${ }^{115}$ Informacja dot. zamiarów utworzenia obiektu sakralnego w miejscowości Jaszczew, IPN-Rz-62/33, k. 13-14. 
ponowne rozpatrzenie sprawy oraz wydanie decyzji o rozbiórce budynku bez przejmowania go na własność państwa, a także jednoczesne wskazanie skarżącemu nieruchomości, gdzie mógłby zrealizować inwestycję ${ }^{116}$. Pozwolenie na budowę kaplicy w Jaszczwi zostało wydane dopiero 15 lutego 1984 roku, po utworzeniu w tej miejscowości parafii ${ }^{117}$.

W 1974 roku SB w Jaśle powzięła wiadomość, że budynek wznoszony przez Stanisławę Świątkowską - pracownicę Urzędu Gminy w Dębowcu na pograniczu wsi Pagórek i Radość (parafia Cieklin) ma zostać zaadaptowany na kaplicę lub plebanię. Po rozpoznaniu jej powiązań z duchowieństwem parafii Cieklin oraz wizyty na placu budowy bp. Bolesława Taborskiego i ks. Stanisława Adamczyka funkcjonariusze SB przekazali posiadane informacje powiatowym strukturom PZPR w Jaśle oraz Wydziałowi do Spraw Wyznań w Krośnie. W wyniku tego przeprowadzono z właścicielką kilka rozmów ostrzegawczych, podczas których zaprzeczała jakoby budynek miał zmienić przeznaczenie oraz przeprowadzono pięć kontroli budowlanych. Warto wskazać, że jedną z rozmów ostrzegawczych prowadził dyrektor krośnieńskiego Wydziału W. Serwatka ${ }^{118}$, a kolejne Naczelnik Gminy Dębowiec, funkcjonariusze Służby Bezpieczeństwa oraz Prokurator Powiatowy z Jasła.

Krośnieński Wydział nakazał cofnięcie zezwolenia na tę budowę oraz sprawdzenie, skąd S. Świątkowska posiada pieniądze na jej realizację ${ }^{119}$. Przeciwdziałając zamiarom utworzenia kaplicy Wydział rekomendował m.in. zaproponowanie właścicielce wydzierżawienia lub zakupu budynku na sklep Gminnej Spółdzielni w Dębowcu ${ }^{120}$. W wyniku działalności operacyjnej ustalono, że poświęcenie kaplicy zaplanowano na 29 września 1976 roku, a przygotowania do tej uroczy-

${ }^{116}$ Pismo do Wojewódzkiego Biura Planowania Przestrzennego i Nadzoru Budowlanego w Krośnie, IPN-Rz-62/33, k. 43-45.

${ }^{117}$ Antoni Szypuła, Historia nowych kościołów w diecezji przemyskiej 1966-1993, t. II (Rzeszów: Biblioteczka Przemyska, 1997), 67.

${ }_{118}$ Notatka dotyczaca zamiarów budownictwa sakralnego w Pagórku Radość, parafia Cieklin, gmina Dębowiec, IPN-Rz-62/25, k. 23-24.

${ }^{119}$ Informacja dot. zamiaru adaptacji budynku mieszkalnego i gospodarczego ob. Świątkowskiej Stanisławy na obiekt sakralny, IPN-Rz-62/25, k. 2-4.

${ }^{120}$ Informacja dot. przekazania budynku mieszkalnego ob. Światkowskiej w Pagórku gm. Dębowiec na obiekt sakralny, IPN-Rz-62/25, k. 6-8. 
stości miały rozpocząć się w poprzedzającą ją noc ${ }^{121}$. W związku z tym wojewódzkie organy władzy postanowiły przejąć budynek na własność państwa. Decyzja ta została wydana przez Naczelnika Gminy Dębowiec 22 września 1976 roku. Z zachowanych dokumentów wynika, że była to szczegółowo zaplanowana akcja. Decyzja ta została przygotowana przez partyjne i państwowe organy wojewódzkie. Treść przedmiotowej decyzji została sporządzona przez dyrektora Wydziału do Spraw Wyznań tow. Serwatkę, przy współpracy tow. Drzymalskiego, którzy 22 września przekazali ją Naczelnikowi Gminy Dębowiec. Jej głównym uzasadnieniem było odstąpienie przez inwestora od zatwierdzonego planu budowy, ,czego wcześniej nie wykazały niedbale przeprowadzone kontrole budowlane”. Tego samego dnia na zlecenie władz zamurowano otwory okienne, wprawiono drzwi i załadowano suteryny zajętego budynku 18 tonami przewiezionych z Krosna nawozów mineralnych. Całą akcją kierował tow. Serwatka, tow. Drzymalski, tow. Wnęk i tow. Kustosz ${ }^{122}$.

Dnia 1 listopada 1978 roku Stanisława Świątkowska została zwolniona z pracy w Urzędzie Gminy Dębowiec. Po tym wydarzeniu i konsultacji z bp. Tokarczukiem ks. Józef Adamczyk postanowił przejąć budynek i zorganizować w nim kaplicę ${ }^{123}$. 19 listopada 1978 roku o godz. 9.00 z kościoła w Cieklinie wyruszyła procesja do Pagórka Radości, gdzie o godz. 11.00 ks. Jan Cag (wikariusz parafii) odprawił nabożeństwo. Podczas niego poinformował, że tego samego dnia o godz. 17.00 przybędzie na to miejsce bp Tokarczuk, aby poświęcić kaplicę ${ }^{124}$. Przez ten czas organy władzy badały gdzie są zatrudnione osoby angażujące się w budowę, czy mają zaległości podatkowe, a także zaciągnięte kredyty.

W związku z tymi wydarzeniami podjęto bardzo szeroką akcję, w którą oprócz Wydziału do Spraw Wyznań zaangażowały się inne

${ }^{121}$ Informacja dot. zamiaru utworzenia obiektu sakralnego w Pagórku Radość, IPN-Rz62/25, k. 30-34.

${ }^{122}$ Plan czynności związanych z przejęciem na rzecz Państwa budynku mieszkalnego w Pagórku-Radość, IPN-Rz-62/25, k. 90.

${ }^{123}$ Antoni Szypuła, Historia nowych kościołów w diecezji przemyskiej 1966-1993, t. III (Sanok: Biblioteczka Przemyska, 1997), 82.

${ }^{124}$ Informacja dot. osób zaangażowanych $w$ przejęcie budynku państwowego na rzecz kościoła rzym.-kat. w Pagórku-Radości, IPN-Rz-62/25, k. 30-31. 
organy władzy oraz partii. Zdarzenie to zakwalifikowano jako włamanie, stąd uczestników postanowiono pociągnąć do odpowiedzialności karnej, czym zajmowała się Komenda Wojewódzka MO. Jednocześnie zakreślono termin dwóch tygodni na wydanie stosownych orzeczeń przez Kolegium ds. Wykroczeń w Dębowcu. Komitet Wojewódzki PZPR opracował ,informację propagandową” na temat działalności bp. Tokarczuka i niektórych księży. Dyrektorzy zakładów pracy zatrudniających osoby zaangażowane w budowę zostali zobowiązani do przeprowadzenia rozmów na podstawie wytycznych WdSW. Zorganizowano także „spotkanie wyjaśniające” w Pagórku i Radości, postanowiono wyegzekwować wszelkie zaległości podatkowe od mieszkańców oraz przeprowadzić kontrolę korzystania $\mathrm{z}$ energii elektrycznej dla oświetlenia zajętego budynku. Wydarzenia te miały także konsekwencje w polityce wojewódzkiej: przeprowadzono naradę z naczelnikami miast i gmin „zagrożonych nielegalnym budownictwem sakralnym” oraz rekomendowano rozbiórkę wszystkich wolno stojących budynków w województwie ${ }^{125}$, co miało uniemożliwić ich ewentualne zajęcie na cele religijne.

W kontekście problematyki budownictwa sakralnego na terenie Polski południowo-wschodniej, w tym województwa krośnieńskiego warto wskazać, że wraz ze strajkami 1980 roku i powstaniem „Solidarności" na tym terytorium pojawiły się postulaty umożliwienia realizacji inwestycji budowalnych przez Kościół. 20 sierpnia 1980 roku bp. Tokarczuk odbył spotkanie z duchownymi zaangażowanymi w budownictwo sakralne, podczas którego wskazał, że warto wykorzystać panujące w kraju rozprężenie polityczne, gdyż w takich okolicznościach władze nie będą reagować na przypadki nielegalnego budownictwa. We wrześniu tego samego roku księża dekanatu rzeszowskiego wystosowali petycję do władz wojewódzkich zawierającą 31 postulatów, w tym dotyczące zgody na budownictwo sakralne ${ }^{126}$. W 1981 roku w diecezji przemyskiej rozpoczęto 38 budów obiektów sakralnych.

${ }^{125}$ Harmonogram czynności wynikających z samowolnego zajęcia obiektu użyteczności publicznej na cele sakralne w miejscowości Pagórek Radość, IPN-Rz-62/25, k. 63-64.

${ }^{126}$ Dariusz Iwanczeko, Opór społeczny a władza $w$ Polsce poludniowo-wschodniej 1980-1989 (Warszawa: Instytut Pamięci Narodowej - Komisja Ścigania Zbrodni przeciwko Narodowi Polskiemu oddział w Rzeszowie, 2005), 142-143. 
Większość z nich odbywała się za zezwoleniem władz, niektóre bez zezwolenia, ale w przeważającej części nie pociągało to za sobą konsekwencji prawnych ${ }^{127}$ dla inicjatorów i uczestników budowy. W niektórych przypadkach zalegalizowano te prace. Przykładowo nielegalną budowę plebani w Kopytowie zalegalizowano w 1983 roku po uregulowaniu spraw własności gruntu ${ }^{128}$.

\section{ZAKOŃCZENIE}

Treścią zasady oddzielenia (rozdziału) kościoła od państwa, zawartej w Konstytucji Polskiej Rzeczypospolitej Ludowej z 1952 roku była przede wszystkim pełna laicyzacja życia społecznego. W ideologii komunistycznej religię uznano za jeden $\mathrm{z}$ czynników utrudniających socjalistyczne przemiany społeczne i ograniczających wolność człowieka. Stąd też jej wyeliminowanie postrzegano jako ważny etap rewolucji komunistycznej. Dlatego wolność sumienia i wyznania oraz mającą ją zabezpieczyć zasadę rozdziału kościoła od państwa pojmowano jako wolność od religii, a działalność instytucji wyznaniowych poddano ścisłej reglamentacji i starano się ograniczyć ich aktywność do obrębu świątyń. Politykę tę konsekwentnie, aczkolwiek różnorodnymi metodami i ze zmienną intensywnością, prowadzono przez cały okres PRL wobec Kościoła Katolickiego.

W tym zakresie działalność Wydziału do Spraw Wyznań Urzędu Wojewódzkiego w Krośnie nie odbiegała od ogólnopolskich standardów. Ciekawym zjawiskiem w działalności krośnieńskiego Wydziału jest częste stosowanie wprost przepisów konstytucji, powołując się w decyzjach, czy planach pracy bezpośrednio na zasadę rozdziału kościoła od państwa. Dominująca część aktywności tej jednostki administracji wyznaniowej skupiała się wokół aktywnej laicyzacji społeczeństwa (zwłaszcza poprzez promowanie świeckiej obrzędowo-

${ }^{127}$ Jan Musiał, „Represje wobec budowniczych kościołów w diecezji przemyskiej”, Studia Rzeszowskie 10 (2003): 127; Iwaneczko, Opór społeczny a władza, 327.

${ }^{128}$ Roczne sprawozdanie Urzędu Gminy Chorkówka z realizacji budownictwa sakralnego, IPN-Rz-62/99, k. 7-8. 
ści) oraz zwalczania budownictwa sakralnego i kościelnego. W obydwu tych obszarach fundamentalną trudnością było znaczne przywiązanie wiernych do Kościoła Katolickiego i jego tradycji religijnej oraz aktywna postawa duchowieństwa diecezji przemyskiej. Pod kierunkiem bp. Tokarczuka duchowieństwo przemyskie prowadziło niespotykaną w skali PRL akcję budownictwa sakralnego (zwłaszcza nielegalnego) oraz intensywną działalność duszpasterską - przede wszystkim wśród młodzieży. Stąd też jakiekolwiek akcje przeciwko inicjatywom Kościoła wymagały długich przygotowań, koordynacji różnych organów władzy, a przez opór ludności często kończyły się fiaskiem. Poza stosowaniem nacisku, czy represji karnych i administracyjnych krośnieński Wydział starał się przeciwdziałać rozwojowi budownictwa sakralnego poprzez angażowanie zainteresowanej nim ludności w czyny społeczne, czy próby przejęcia nieruchomości przeznaczonych na budowę obiektów sakralnych na cele ,użyteczności publicznej”.

Politykę wyznaniową województwa krośnieńskiego prowadzono w ścisłej współpracy Wydziału do Spraw Wyznań, struktur bezpieczeństwa oraz Partii. W przypadku wyciągania konsekwencji wobec świeckich zaangażowanych w nielegalne budownictwo sakralne współdziałano także z ich zakładami pracy. Zachowane materiały świadczą, że dopiero po ustaleniu celów politycznych podejmowania danych akcji szukano prawnych metod ich realizacji. Głównymi kryteriami stosowania przepisów prawa nie była ich prawidłowa wykładnia, ale ocena postawy politycznej duchowieństwa oraz pryncypia polityczne wyznaczane przez organy centralne i KW PZPR w Krośnie. Styl działania Wydziału do Spraw Wyznań w Krośnie pozwala postawić tezę, że realizował on politykę budowania Polski Ludowej, jako państwa quasi wyznaniowego, gdzie doktryna religijna zostaje zastąpiona ideologią komunistyczną, ceremonie religijne ,świecką obrzędowością”, a obiekty sakralne różnego rodzaju budynkami publicznymi.

\section{BIBLIOGRAFIA}

Banaszak, Bogusław. „Konstytucyjne założenia podstawowych praw, wolności i obowiązków obywatelskich i ich realizacja w praktyce". W: Konstytucja 
PRL po 30 latach jej obowiazywania, red. Krzysztof Działocha, 113-128. Wrocław: Wydawnictwo Uniwersytetu Wrocławskiego, 1983.

Biliński, Albin. Marksistowska a katolicka koncepcja wolności sumienia $i$ wyznania. Poznań: Politechnika Poznańska. Materiały historyczno-metodyczne, 1973.

Dziobek-Romański, Jacek. „Ewolucja normatywna regulacji stosunków państwo-Kościół w Polsce Ludowej (1944-1989)". W: Bilateralizm w stosunkach państwowo-kościelnych, red. Marek Bielecki, 61-91. Lublin: Wydawnictwo KUL. 2011.

Dziurok, Adam, Marek Gałęzowski, Łukasz Kamiński, Filip Musiał. Od niepodległości do niepodległości. Historia Polski 1918-1989. Warszawa: Instytut Pamięci Narodowej - Komisja Ścigania Zbrodni przeciwko Narodowi Polskiemu, 2010.

Fiejdasz, Lidia. „Opór społeczeństwa Rzeszowszczyzny wobec działań Wydziału do Spraw Wyznań”. Studia z Prawa Wyznaniowego 13 (2010): 117-142.

Fiejdasz, Lidia. „Rola Wydziału do Spraw Wyznań Prezydium Wojewódzkiej Rady Narodowej w Rzeszowie w laicyzacji służby zdrowia". Studia z Prawa Wyznaniowego 12 (2009): 199-218.

Fiejdasz, Lidia. Organizacja referatów do spraw wyznań przy prezydiach powiatowych rad narodowych w latach 1950-1957 na terenie województwa rzeszowskiego. Prace Historyczno-Archiwalne 22 (2010): 169-182.

Fiejdasz, Lidia. Stosowanie prawa przez Wydział do Spraw Wyznań w Rzeszowie wobec duchownych Kościoła Katolickiego w latach 1950-1973. Lublin: Wydawnictwo KUL, 2012.

Godlewski, Jerzy Feliks. Założenia polityki wyznaniowej w PRL. Warszawa: Wyższa Szkoła Nauk Społecznych przy KC PZPR, 1984.

Godlewski, Jerzy, Henryk Jabłoński. Prawo a religia. Warszawa: Wiedza Powszechna, 1988.

Górowska, Beata. „Rozdział kościoła i państwa w PRL”. W: Francuska ustawa z 9 grudnia 1905 roku o rozdziale kościołów i państwa z perspektywy stu lat, red. Michał Pietrzak, 179-197. Warszawa: Wydawnictwo LIBER, 2007. Grudzień, Janusz. Zasady polityki wyznaniowej PRL. Wydanie trzecie poprawione i uzupetnione. Warszawa: Książka i Wiedza, 1971.

Iwanczeko, Dariusz. Opór społeczny a władza w Polsce południowo-wschodniej 1980-1989. Warszawa: Instytut Pamięci Narodowej - Komisja Ścigania Zbrodni przeciwko Narodowi Polskiemu oddział w Rzeszowie, 2005. 
Iwaneczko, Dariusz. Zmierzch dekady Gierka. Polska poludniowo-wschodnia 1875-1980. Rzeszów: Instytut Pamięci Narodowej Komisja Ścigania Zbrodni przeciwko Narodowi Polskiemu oddział w Rzeszowie, 2016.

Krasowski, Krzysztof. „Koncepcje regulacji stosunków między państwem a Kościołem Katolickim w Polsce w latach 1945-1952 i ich realizacja”. W: Vetera novis augere. Studia i prace dedykowane profesorowi Wactawowi Uruszczakowi, t. 1, red. Stanisław Grodziski, Dorota Malec, Anna Karabowicz, Marek Stus, 459-478. Kraków: Wydawnictwo Uniwersytetu Jagiellońskiego, 2010.

Krawczyk, Michał. „Organy państwowo-partyjne odpowiedzialne za wytyczanie i realizowanie polityki wyznaniowej PRL". Zeszyty Naukowe Uniwersytetu Przyrodniczo-Humanistycznego w Siedlcach 89 (2011): 211-225.

Krukowski, Józef. Kościót i państwo. Podstawy relacji prawnych. Lublin: Redakcja Wydawnictw Katolickiego Uniwersytetu Lubelskiego, 1993.

Lang, Wiesław, Jerzy Wróblewski, Sylwester Zawadzki. Teoria państwa i prawa, wyd. III zmienione. Warszawa: Państwowe Wydawnictwo Naukowe, Warszawa. 1986.

Lasota, Marek. „Zadanie: dezintegracja Kościoła w Polsce”. W: Znak, któremu sprzeciwiać się będą. Komunistyczne państwo wobec Kościoła $w$ Polsce, red. Jarosław Szarek, 69-78. Kraków: Instytut Pamięci Narodowej - Komisja Ścigania Zbrodni przeciwko Narodowi Polskiemu oddział w Krakowie, 2004.

Leszczyna Henryk. „Kilka uwag na temat demokracji socjalistycznej”. Studia Iuridica. Problemy demokracji socjalistycznej 7 (1980): 39-50.

Majka, Józef. „Kościół w Polsce po drugiej wojnie światowej”. Chrześcijanin w Świecie 1 (1994): 6-22.

Mazgaj, Marian Stanisław. Church and State in Communist Poland. A History, 1944-1989. McFarland \& Company, Inc., Publishers, 2010.

Misztal, Henryk. Polskie prawo wyznaniowe. Zagadnienie wstepne. Rys historyczny. Lublin: Wydawnictwo KUL, 1997.

Misztal, Henryk, Artur Mezlglewski. „Zakres kompetencji, styl działania i cele Urzędu do Spraw Wyznań”. W: Prawo i polityka wyznaniowa w Polsce Ludowej: materiały II Ogólnopolskiego Sympozjum Prawa Wyznaniowego (Kazimierz Dolny, 26-28 października 2004), red. Artur Mezglewski, Piotr Stanisz, Marta Ordon, 33-70. Lublin: Wydawnictwo KUL, 2005.

Musiał, Jan. „Represje wobec budowniczych kościołów w diecezji przemyskiej”. Studia Rzeszowskie 10 (2003): 117-128. 
Mysłek, Wiesław. Polityka wyznaniowa Polski Ludowej. Przesłanki i realizacja. Warszawa: Państwowe Wydawnictwo „Iskry”, 1970.

Olszówka, Marcin. Konstytucja PRL a system źródet prawa wyznaniowego do roku 1989. Warszawa: Oficyna Wydawnicza Uczelni Łazarskiego, 2016.

Osuchowski, Janusz. „Wolność sumienia i wyznania w przyszłej konstytucji PRL". Państwo i Prawo 5 (1989): 29-42.

Pietrzak, Michał. Demokratyczne, świeckie państwo prawne. Warszawa: Wydawnictwo LIBER, 1999.

Pietrzak, Michał. „Państwo i Kościół w obecnej i przyszłej konstytucji polskiej”. Rocznik Teologiczny 1 (1993): 281-299.

Prawo państwowe Polskiej Rzeczypospolitej Ludowej, red. Janina Zakrzewska. Łódź-Warszawa: Państwowe Wydawnictwo Naukowe, 1964.

Rogowska, Barbara. Polityka polskich wtadz komunistycznych wobec Kościota rzymskokatolickiego. Wrocław: Wydawnictwo Uniwersytetu Wrocławskiego, 2013.

Seidler, Grzegorz Leopold, Henryk Groszyk, Jan Malarczyk. Wstęp do teorii państwa i prawa. Lublin: Uniwersytet Marii Curie-Skłodowskiej, 1982.

Szymanek, Jarosław. „Formy prawnej instytucjonalizacji rozdziału państwa i kościoła”. Studia z Prawa Wyznaniowego 11 (2008): 47-85.

Szymanek, Jarosław. „Kształtowanie normatywnego systemu stosunku państwa do organizacji religijnych w Związku Radzieckim”. Studia z Prawa Wyznaniowego 7 (2004): 95-114.

Szypuła, Antoni. Historia nowych kościołów w diecezji przemyskiej 1966-1993, t. III. Rzeszów: Biblioteczka Przemyska, 1997.

Szypuła, Antoni. Historia nowych kościołów w diecezji przemyskiej 1966-1993, t. II, Sanok: Biblioteczka Przemyska, 1997.

Świątkowski, Henryk. Wyznaniowe prawo państwowe. Problematyka prawna wolności sumienia w PRL. Warszawa: Państwowe Wydawnictwo Naukowe, 1962.

Turska, Anna. „Zasady samorządności społecznej w świetle teorii i praktyki samorządu mieszkańców”. Studia Iuridica. Problemy demokracji socjalistycznej 7 (1980): 51-64. 
THE CONSTITUTIONAL PRINCIPLE OF SEPARATION OF CHURCH AND STATE IN THE OPERATION OF THE DEPARTMENT OF RELIGIOUS AFFAIRS IN THE VOIVODESHIP OFFICE IN KROSNO AGAINST THE CATHOLIC CHURCH

\section{Summary}

The subject matter of this article is the analysis of the action of the Department for Religious Affairs in Krosno against the Catholic Church in the light of the constitutional principle about Church and State separation. The Constitution of the Polish People's Republic of 22 July 1952 set forth the separation of Church and State (Art. 70, para. 2) and stipulated that the Church can freely carry out its religious functions (Art. 70, para. 1). This provision applied also to other religious associations. Under the constitutional law at that time, this freedom was understood as the freedom to proclaim doctrine, organize religious assemblies, provide ministry and teaching, establish religious orders, and maintain contacts with the believers abroad. The law was used to discriminate against the Church, which became a kind of standard. For example, legal measures, especially penal and administrative sanctions, were employed to block and restrict the construction of buildings used for religious purposes. The constitutional principle concerning Church and State separation was understood by the Department of Religious Affairs in Krosno as a total secularization of social life. For example, it was used to justify taking actions against the development of buildings used for religious purposes or against any pastoral activities undertaken by the Catholic clergy, especially concerning the youth ministry.

Key words: the Polish People's Republic; the Department for Religious Affairs; the separation of Church and State; sacred architecture, State - Church relations

Słowa kluczowe: Polska Rzeczpospolita Ludowa; Wydział do Spraw Wyznań; oddzielenie państwa od kościoła; budownictwo sakralne, stosunki państwo - kościół 